\section{| \\ I I I}

\section{US Army Corps}

of Engineers ${ }_{\circledast}$

Engineer Research and

Development Center

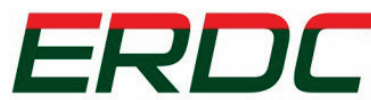

INNOVATIVE SOLUTIONS

for a safer, better world

Net Zero Planning for Fort Leonard Wood

\title{
Black Swan Event Assessment for Fort Leonard Wood, Missouri
}

Grace M. Diaz-Estrada and James D. Westervelt

March 2016
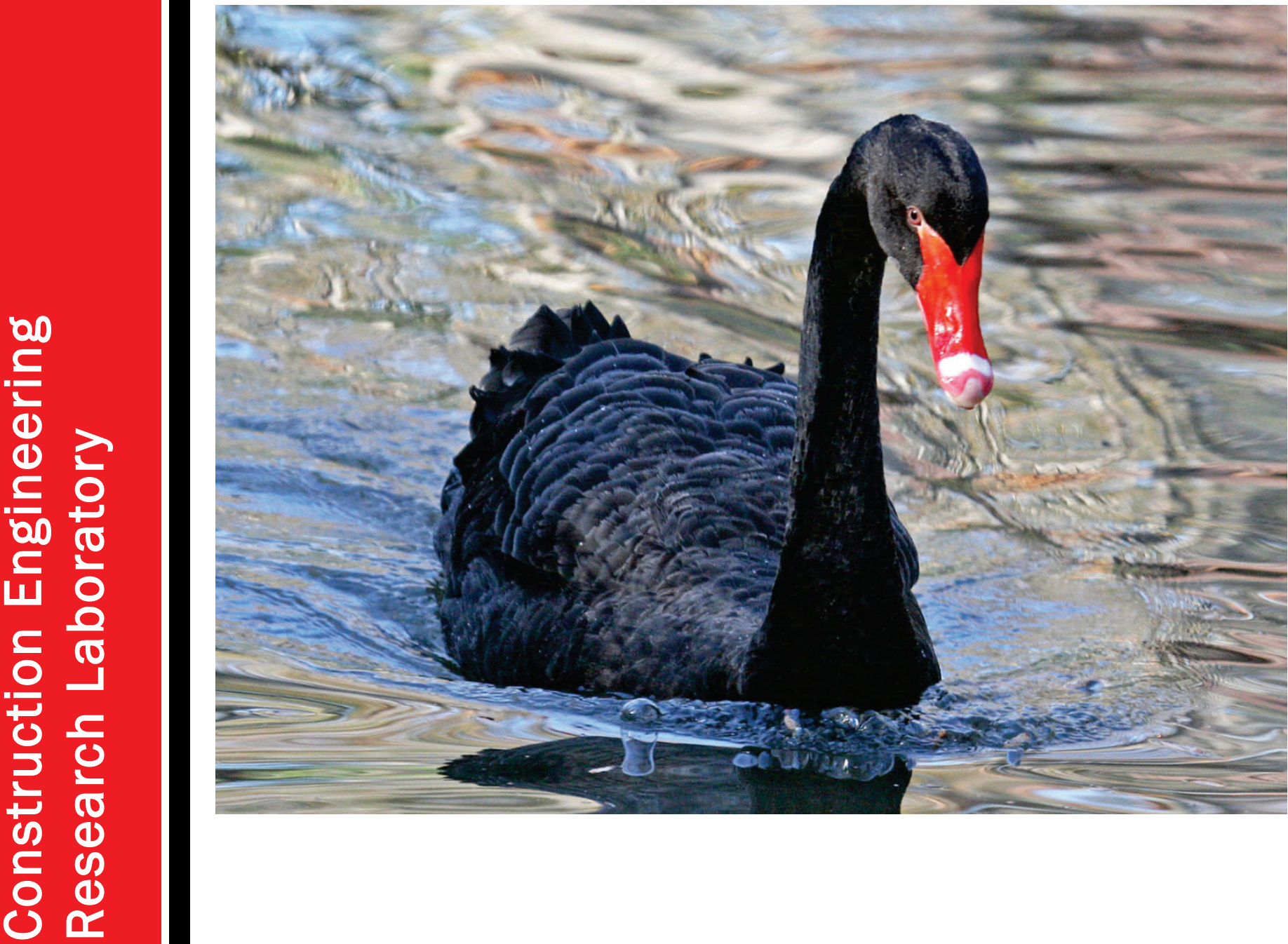
The U.S. Army Engineer Research and Development Center (ERDC) solves the nation's toughest engineering and environmental challenges. ERDC develops innovative solutions in civil and military engineering, geospatial sciences, water resources, and environmental sciences for the Army, the Department of Defense, civilian agencies, and our nation's public good. Find out more at www.erdc.usace.army.mil.

To search for other technical reports published by ERDC, visit the ERDC online library at http://acwc.sdp.sirsi.net/client/default. 


\section{Black Swan Event Assessment for Fort Leonard Wood, Missouri}

James D. Westervelt

Construction Engineering Research Laboratory

U.S. Army Engineer Research and Development Center

2902 Newmark Drive

Champaign, IL 61822

Grace M. Diaz-Estrada

University of Puerto Rico at Mayagüez

Alfonso Valdez Cabian,

Mayagüez 00680, Puerto Rico

Final report

Approved for public release; distribution is unlimited.

Prepared for U.S. Army Corps of Engineers

Washington, DC 20314-1000

Under MIPR 10599341, “Integrated NetZero Roadmap Plan for Fort Leonard Wood” 


\section{Abstract}

Emergency preparation typically involves evaluating disaster potential and consequences, followed by disaster preparedness. Potentials are informed by history, with the easy human belief that we must obviously prepare for the past. There is a class of disasters that involve events that may not have been anticipated, but in hindsight appear to be obviously overlooked. This report attempts to identify such black swan events, potential disasters in the Fort Leonard Wood area that might well attract more attention in future planning exercises.

DISCLAIMER: The contents of this report are not to be used for advertising, publication, or promotional purposes. Citation of trade names does not constitute an official endorsement or approval of the use of such commercial products. All product names and trademarks cited are the property of their respective owners. The findings of this report are not to be construed as an official Department of the Army position unless so designated by other authorized documents. 


\section{Contents}

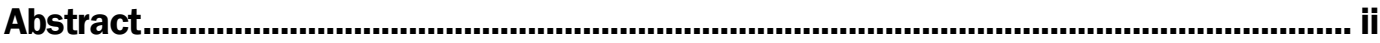

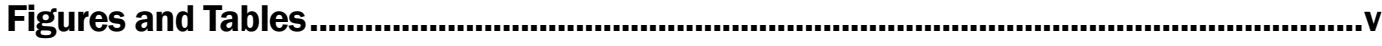

Preface

Unit Conversion Factors...................................................................................................viii

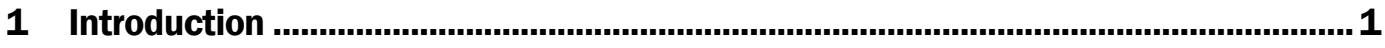

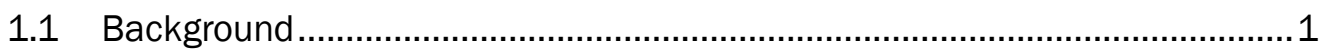

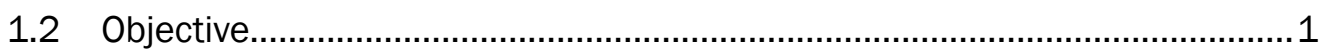

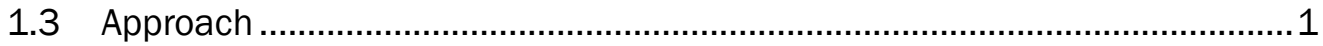

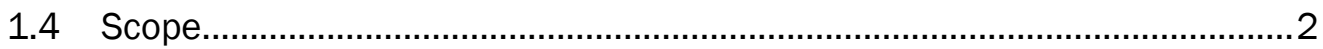

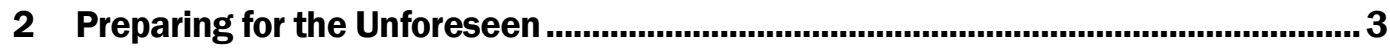

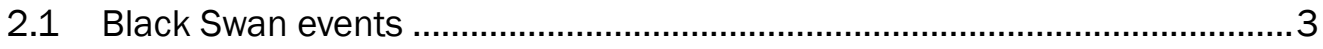

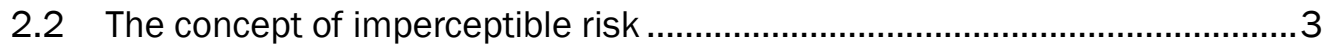

2.3 Analyzing the unpredictable ..................................................................

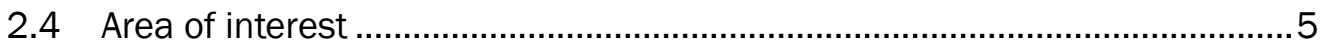

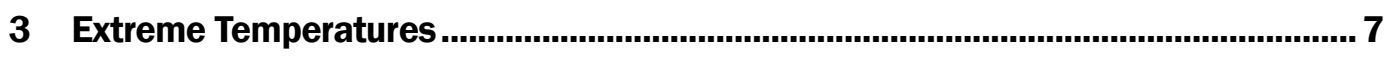

3.1 Potential events .................................................................................... 7

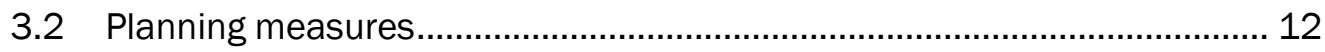

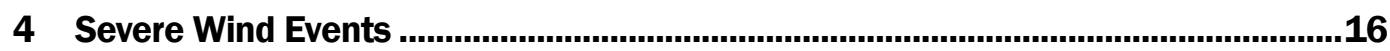

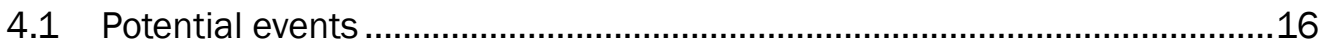

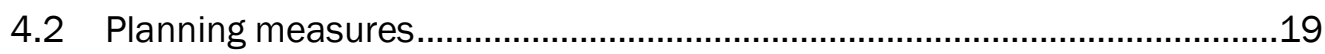

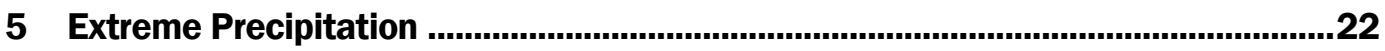

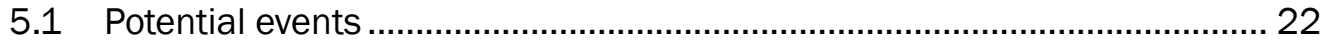

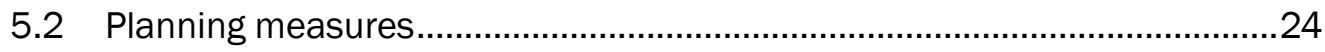

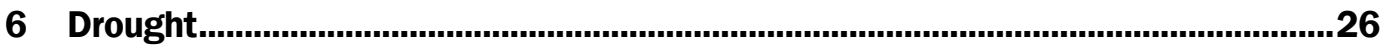

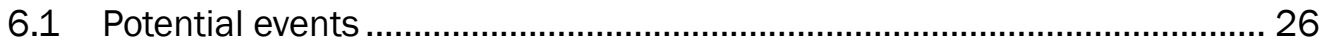

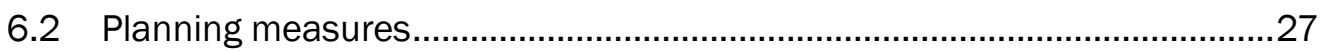

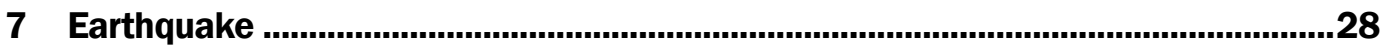

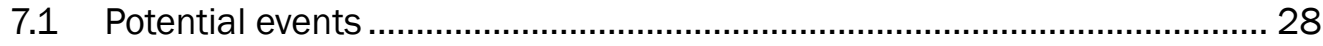

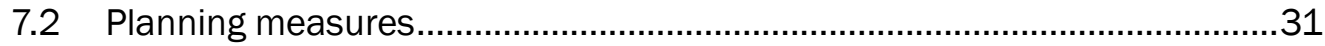

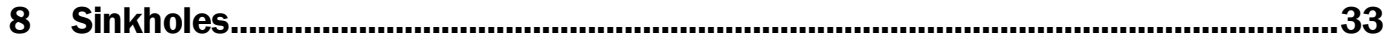

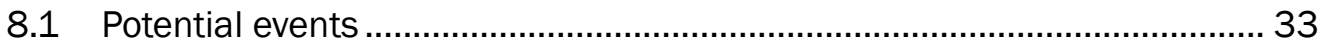

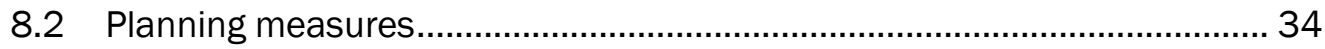




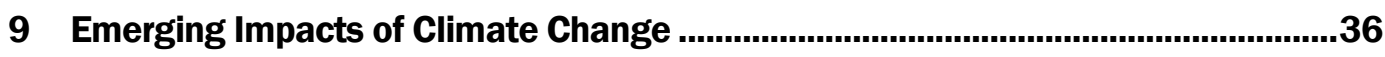

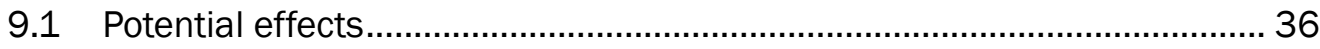

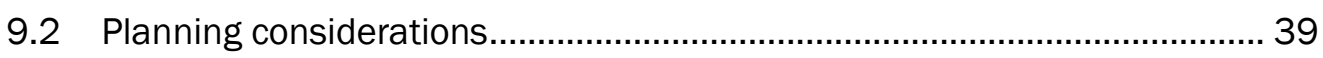

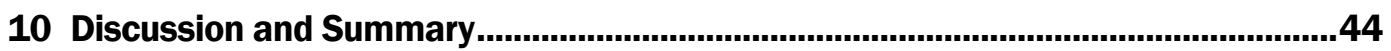

References.........................................................................................................................46

Report Documentation Page 


\section{Figures and Tables}

\section{Figures}

Figure 1. Fort Leonard Wood and surrounding Missouri counties.

Figure 2. Missouri average winter and summer temperatures 1895-2014.

(Source: Missouri Climate Center/NOAA.)

Figure 3. Missouri hypothermia mortality, 1989 to 2012. (Source: Missouri Department of Health and Senior Services.)

Figure 4. Hypothermia related deaths in winter seasons from 1979 to 2012. (Source: Missouri Department of Health and Senior Services.)

Figure 5. Historic temperature ranges and extremes from Fort Leonard Wood weather station. (Source: National Weather service; image from Weatherspark.com.)

Figure 6. Characterization of climate zones for the recommended levels of insulation.(Source: North American Insulation Manufacturers Association.)

Figure 7. Green roof at the Transportation Deployment support area at Fort Bragg. (Source: LiveRoof Brand webpage.).

Figure 8. Maximum wind velocities and corresponding zones in the U.S. according to FEMA standards category and using ASCE 7-05. (Source: FEMA.)

Figure 9. Estimated trajectory and impact area of the Joplin tornado in Missouri on May 22, 2011. (Source: U.S. Army Corps of Engineers, Kansas City District.)

Figure 10. Tornado intensities and path near Fort Leonard Wood, Missouri.

(Source: Tornado History Project webpage.)

Figure 11. Safe room construction in Sioux City, lowa. (Source: Dave Gatley, FEMA.)

Figure 12. Safe room condition after a tornado hit Piedmont, Oklahoma. (Source:

Syracuse Media Group webpage.).

Figure 13. Tracks of historic hurricanes. (http://coast.noaa.gov/hurricanes.).

Figure 14. Average number of severe thunderstorm watches per year. (Source: http://www.spc.noaa.gov/wcm/20ysvra.png.)

Figure 15. Historic Missouri drought index. (Source:

http://mogreenstats.com/2014/02/04/missouri-wetter-than-average-in-2013.)

Figure 16. Potential earthquake acceleration potential as a percent of gravity for the year 2008 and 2014. (Source: USGS.)

Figure 17. Missouri seismicity map for the years 1973 to 2012. (Source: USGS

Earthquake Hazard Program.)

Figure 18. Missouri seismic hazard map. (Source: USGS Earthquake Hazard

Program).

Figure 19. Seismic building code compliance in high-risk counties. (Source: 2010

ISO BCEGS Data.)

Figure 20. Sample sinkhole. (Source:

http://blogs.mo.gov/geology/tag/sinkhole/) 
Figure 21. Missouri sinkhole locations. (Source: Missouri Department of Natural Resources, http://dnr.mo.gov/geology/geosrv/envgeo/sinkholes.htm) ..........................34

Figure 22. Potential Fort Leonard Wood sinkholes shown in red. ......................................35

Figure 23. Historic increasing temperature trend in Midwest. (Source: National Climate Assessment.).

Figure 24. Recent increases in very heavy precipitation. (Source: National Climate

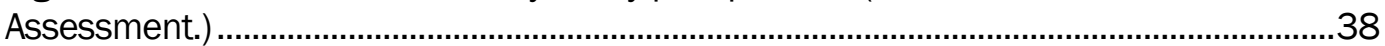

Figure 25. Forecasted change in fire risk days...........................................................

Figure 26. Forecasted change in heat-restricted training days...........................................40

Figure 27. Projected ecosystem shifts. ...............................................................................43

\section{Tables}

Table 1. Missouri temperature extremes. (Source: Missouri Climate Center.) ...................... 8

Table 2. Recommended levels of fiberglass, rock wool, and slag wool insulation for Zone 4. (Source: North American Insulation Manufacturers Association.).....................13

Table 3. Insulation type, materials, and applications. (Source: U.S. DoE.) ...........................14

Table 4. Extreme Missouri tornado events. (Source: Missouri Climate Center.) ..................17

Table 5. Area of Interest tornado history summary from 1950 to 2012. (Source:

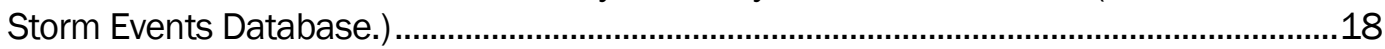

Table 6. Missouri precipitation extremes. (Source: Missouri Climate Center.)....................24

Table 7. Richter scale destruction level..........................................................................28

Table 8. Estimated change in energy consumption under climate temperature increases of $3{ }^{\circ} \mathrm{C}$ and $6{ }^{\circ} \mathrm{C}$. 


\section{Preface}

This study was conducted for the Plans, Analysis, and Integration Office (PAIO) at U.S. Army Garrison Fort Leonard Wood under Military Interdepartmental Purchase Request (MIPR) 10599341, "Integrated NetZero Roadmap Plan for Ft. Leonard Wood." The technical monitor was Mark Premont (ATZT-SPAR).

The work was performed by the Engineering Processes Branch of the Facilities Division (CF), U.S. Army Engineer Research and Development Center, Construction Engineering Research Laboratory (ERDC-CERL). At the time of publication, the ERDC-CERL Principal Investigators were Susan Bevelheimer and Annette Stumpf, both of CFN and Dr. James D. Westervelt, CNN. Chuck Schroeder was Chief, CEERD-CFN and Chris Rewerts was Chief, CEERD-CNN. The Assistant Director of the Center for the Advancement of Sustainability Innovations (CASI) was Franklin H. Holcomb. The Deputy Director of ERDC-CERL was Dr. Kirankumar Topudurti and the Director was Dr. Ilker Adiguzel.

COL Bryan S. Green was the Commander of ERDC, and Dr. Jeffery P. Holland was the Director. 


\section{Unit Conversion Factors}

\begin{tabular}{|l|c|l|}
\hline \multicolumn{1}{|c|}{ Multiply } & By & \multicolumn{1}{c|}{ To Obtain } \\
\hline degrees Fahrenheit & $(\mathrm{F}-32) / 1.8$ & degrees Celsius \\
\hline knots & 0.5144444 & meters per second \\
\hline miles (US statute) & $1,609.347$ & meters \\
\hline miles per hour & 0.44704 & meters per second \\
\hline
\end{tabular}




\section{Introduction}

\subsection{Background}

Military installations exist to support designated missions, and the potential for disruptions to those missions need to be identified and prepared for in installation design and various management plans. These include Installation Master Plans, Integrated Natural Resource Management Plans (INRMPs), Integrated Cultural Resource Management Plans (ICRMPs), Integrated Pest Management Plans (INPMPs), encroachment management plans and programs, storm water and other utility system management, facility maintenance and repair cost models, installation-level water resource management plans, and emergency preparedness and response planning. Through planning, an installation seeks to establish and maintain resilience in the face of future disasters. This involves protecting critical infrastructure, establishing and maintaining backup systems, and developing and practicing response and contingency plans.

Preparing for repeat events is important, but generally not entirely sufficient. Sometimes unexpected types or intensities of disasters can be initially surprising, but in hindsight, less than surprising. Preparing to withstand and bounce back from unexpected disasters is important, yet tricky. An analysis to assess the potential impacts of such disasters is important for any community.

\subsection{Objective}

The objective of this project is to identify potential black swan events that could have a serious impact on Fort Leonard Wood facilities or operations and recommend planning measures that would facilitate effective responses by the garrison.

\subsection{Approach}

The usual risk-assessment methodology focuses on high probability events, ignoring low probability with high impact threats, or black swan events for an installation. Therefore, neither risk preparation nor mitigation is developed for them. The Construction Engineering Research Laboratory of the U.S. Army Engineer Research and Development Center (ERDC-CERL) is conducting this research with the objective of defining a 
methodology or guideline for exploring the potential for black swan events. Additionally, with the obtained results, several alternatives are provided as to prepare or lower the impact associated with the threat. This approach was applied for Fort Leonard Wood, using the state of Missouri and more specifically, nine counties, as the area of interest.

\subsection{Scope}

The scope of the project provides an approach for acknowledging and preparing for possible environmental black swan events and to test that methodology for our case study: Fort Leonard Wood. This project focuses on historical natural events and recorded extremes that could, if repeated, cause catastrophic effects for Fort Leonard Wood. However, development of a comprehensive understanding must include consideration of potential black swan events arising anthropogenic effects on larger-scale climate conditions. 


\section{Preparing for the Unforeseen}

\subsection{Black Swan events}

The term black swan is used to characterize a phenomenon that has been perceived to be impossible or highly improbable until it unexpectedly emerges into the public domain of awareness. The term originates with a voyage of the Dutch explorer Willem de Vlamingh, who discovered black swans in a previously uncharted location in Western Australia. Europeans had, for an understandable reason, assumed that all swans were white. However, once de Vlamingh's discovery was reported, the existence of black swans was not considered improbable at all. This response of acknowledging the improbable as obvious after it occurs is a common human reaction to novel occurrences. Today, a "black swan event" refers to the occurrence of a critical event with no known precedent, often causing major damage or other impacts to a civilization (Taleb 2007.) When considered at all in planning and policy making, black swan events are viewed as "outliers," either unprecedented in the area of interest (AOI) or rare in any location. Even if they are not addressed in usual risk-management practice, once they occur they are often viewed after the fact as having been virtually inevitable.

Predicting the timing of a black swan event is improbable at best. However, recompiling historic data and analyzing it in new ways can hint at the nature and probability for highly disruptive events that have not been envisioned in conventional risk-management activities. This sort of analysis is important for purposes of planning for disruptive events that seem only a remote possibility in everyday thinking. While well timed prediction is not feasible, preparing risk-mitigation alternatives for reality-based worstcase scenarios is feasible and advisable in order to reduce the impacts on installation operations and personnel.

\subsection{The concept of imperceptible risk}

By definition, a black swan event is inherently elusive to plan for. Planning would begin with a risk assessment, but signs of risk may be barely perceptible without a specialized analysis of historic data that may contain clues. 
A typical risk assessment begins by defining the prospective hazard, area of interest (AOI), resources available for mitigation, scope, and specific tasks. The organization must then create a risk preparation team through selection of qualified professionals. This team will start by reviewing, analyzing, and updating existing documentation (such as procedures) from events that the previous risk assessments used. With the gathered information, the risk assessment team takes into account expected events, and calculates the organization risk and vulnerability due to each event separately and in combination. These values depend on the risk assessment methodology and help to categorize the risk (Landoll 2011). The basic method evaluates the risk by multiplying the probability of occurrence with the expected impact of the event. Another method, the failure mode and effects analysis (FMEA) also includes the detection into its calculation.

The scope of the risk assessment is defined by what the company determines is an asset. An asset is something of importance to the company such as employees, buildings, documents, etc. The process consists of enumerating all of the company assets and assigning a value to each of them, creating countermeasures, and estimating probable loss. The next step in a risk assessment is to list threat agents or threats most probable to cause a negative impact on the installation. Examples of threat agents are destructive natural events, disaffected employees, technology hackers and thieves, and government and private-sector espionage (Landoll 2011). Vulnerabilities are flaws that the organization has that can permit threats to damage the assets. These must be studied and documented both before and after the execution of recommendations. Finally, based on the previous steps, the risk that an asset has, due to an event, is determined. The most important thing to notice is that a risk assessment only takes into account known probability threats in its analyses.

\subsection{Analyzing the unpredictable}

A risk assessment only tackles those events with significant probability, ignoring events considered uncommon or with low probability of occurrence for that geographic area. This over simplification of environmental threats leaves gaps in an organization's preparedness for disasters. Recent events, both anthropogenic and natural, such as the Fukushima nuclear power plant failure in March 2011 and the Haiti earthquake in January 2010, are examples that risk management is not enough. With the previous statements in mind, it is important to broaden the "threat picture" in order to reduce the impact of an event that wasn't previously included. 
In general, the process of preparing for a black swan event can start by considering different "what-if" situations. This is included as part of a test called disrupter analysis, used for complementing the typical risk assessment. The first step is to delineate the area of interest. The team in charge of the disrupter analysis test must expand the list made by the risk management team by identifying possible catastrophes, either environmental, technological, or anthropogenic, just to name a few. These are then listed and categorized by the impact they could cause to an installation.

After making the list, the real analysis can begin. The impact of one event or multiples simultaneously can be questioned, disregarding their probabilities of occurrence, which means that more risks and impacts will be acknowledged and accounted. Mitigation plans are then designed for every scenario in the analysis. In these plans, emphasis should also be given to resilience, as to reduce the risk of failure. One example of resilience is having extra equipment (or stand-by equipment) in case the main one fails. This would drastically affect the recovery time of the organization. The addition of resilience may provide a broader insight of an installation's sensitive areas in order to make viable better management techniques, improving the risk assessment. Physical or engineering resilience is related to how quickly systems can be reestablishment or recovered to the previous state. On the other hand, the ecological and social resilience has a broader spectrum since it also includes the ability to adapt and to learn from the event that occurred for continual improvement of resilience. Both complement each other and are needed for better risk management.

Several studies related to resilience are being done on army installations. One of them, a model called Military Installation Resilience Assessment (MIRA) was developed for examining resilience of military installations on low-probability events (Sikula et al. 2015). The assessment combines social, ecological, and physical resilience as well as risk management techniques to identify sensitive areas and formulate solutions that include adaptation. All of the processes explained will be applied to the events being analyzed in this document.

\subsection{Area of interest}

The AOI defined for this study is Fort Leonard Wood, Pulaski County, Missouri, and the eight surrounding counties shown in Figure 1. The installation is located in the south central Missouri Ozarks and covers more than 62,000 acres. Its facilities and lands are used to train around 80,000 
military and civilian personnel every year. Fort Leonard Wood is home to many schools that serve the entire Army, such as the U.S. Army Engineer Chemical, Biological, Radiological, and Nuclear School, the Maneuver Support Center of Excellence, and the Military Police School. The entire $\mathrm{AOI}$ is situated within roughly a $50 \mathrm{~km}$ radius of the installation.

Figure 1. Fort Leonard Wood and surrounding Missouri counties.

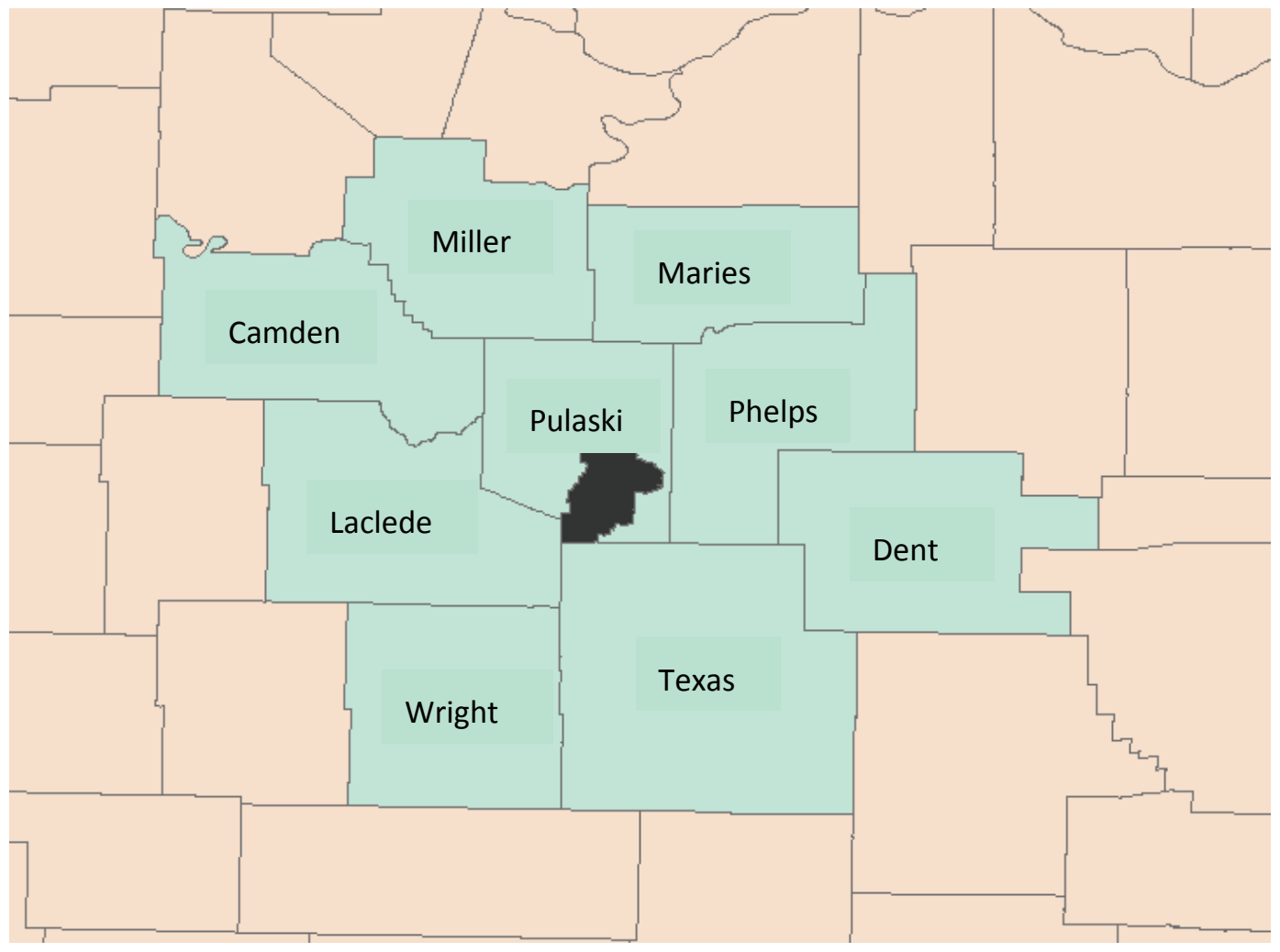

Each chapter of this report considers a different category of natural phenomena capable of producing extremes that would be classified as black swan events in the Fort Leonard Wood region. Potential black swan events will be uncovered based on a review of measured historic extremes near the AOI. Effects on the installation are considered and suggestions are offered for planning measures that could help to prepare for, mitigate, and recover from the predictable results of improbable-but-feasible disasters.

The text includes a brief discussion of climate change with respect to how trends measured in recent decades could affect prospective weather extremes and related risk. 


\section{Extreme Temperatures}

\subsection{Potential events}

Extreme temperatures including the frequency, length, and intensity of temperature events are extensively studied due to how it impacts humans, structures, and the environment. Temperature data can be obtained from the state climate center, the National Climatic Data Center (NCDC) database or the Storm Events Database, both created by the National Oceanic and Atmospheric Administration (NOAA). The NCDC can be used to obtain the data available for weather stations in every county in the United States. An additional source for identifying historic extreme weather events is the Storm Events Database from NOAA. The associated website provides the opportunity to select the event type (48 events total), the state, counties, and length of the analysis. The database includes occurrences of weather events with high intensity and unusual weather phenomena. However, this database only has information about the 48 event types from 1995 to the present and tornado information from 1950 to present.

In general, due to the lack of topographic barriers and inland location, the temperature range and variability in Missouri is large. This variability makes it uncommon to have extensive periods of hot or cold weather in the area. The Missouri Climate Center website enumerates several extreme temperature events through the years 1900 to 2000. These are shown in Table 1. Figure 2 details annual average winter and summer temperature values from 1895 to 2014. Average winter temperatures have ranged from a low of about $24{ }^{\circ} \mathrm{F}$ to a high of about $40{ }^{\circ} \mathrm{F}$, a range of about $16^{\circ} \mathrm{F}$. Similarly, average summer temperatures have been recorded to range from 71 ${ }^{\circ} \mathrm{F}$ to $82{ }^{\circ} \mathrm{F}$. The coldest temperature recorded for Missouri was $-40{ }^{\circ} \mathrm{F}$ on February 13,1905 and the highest on July 14,1954 with a value of $118^{\circ} \mathrm{F}$. This wide range of temperature affects Fort Leonard Wood structures and workforce in several ways. For example, cold weather is associated with hypothermia, frostbite, and possible death. Hypothermia occurs when the body temperature drops below $35{ }^{\circ} \mathrm{C}$ (or $94.1{ }^{\circ} \mathrm{F}$ ). The Missouri Department of Health and Senior Services has estimated 569 fatalities from 1979 to 2012 from hypothermia. Most of the deaths are concentrated in the winter season (from October to March) as shown in Figure 3. At least five 
people have died from hypothermia yearly, according to earlier data. Annual hypothermia related deaths are shown in Figure 4.

Table 1. Missouri temperature extremes. (Source: Missouri Climate Center.)

\begin{tabular}{|l|l|}
\hline \multicolumn{1}{|c|}{ Event } & \multicolumn{1}{c|}{ Year } \\
\hline $\begin{array}{l}-40{ }^{\circ} \mathrm{F} \text { (Coldest temperature recorded. } \\
\text { Location: West -central Missouri }\end{array}$ & February 13, 1905 \\
\hline $\begin{array}{l}\text { Extreme diurnal temperature range. } 50^{\circ} \mathrm{F} \text { fall over three } \\
\text { hours and } 65-70^{\circ} \mathrm{F} \text { over } 18 \text { to } 24 \text { hours. }\end{array}$ & November 11, 1911 \\
\hline Summer heat & 1913 \\
\hline $\begin{array}{l}\text { Hottest month and hottest summer on record. } \\
\text { Average: } 86.1^{\circ} \mathrm{F} \text { and } 81.9^{\circ} \mathrm{F}, \text { respectively. }\end{array}$ & July 1934 \\
\hline Coldest month on record. Average: $15.3^{\circ} \mathrm{F}$. & January 1940 \\
\hline $\begin{array}{l}\text { Hottest temperature ever recorded } 118^{\circ} \mathrm{F}, \text { West and east- } \\
\text { central Missouri }\end{array}$ & July 14, 1954 \\
\hline Coldest march on record for state & 1960 \\
\hline Coldest winter for state. Average: $24.1{ }^{\circ} \mathrm{F}$ & $1978-79$ \\
\hline Summer heat wave & 1980 \\
\hline Coldest December on record for the state & 1983 \\
\hline $\begin{array}{l}\text { Ten out of twelve winters have been warmer than the 100- } \\
\text { year temperature normal. }\end{array}$ & 1990 's \\
\hline
\end{tabular}


Figure 2. Missouri average winter and summer temperatures 1895-2014.

(Source: Missouri Climate Center/NOAA.)

\section{Missouri Average Winter Temperature}

(Dec-Jan-Feb, 1895-2014*)

*The winter of 2013 is defined as Dec 2013 and Jan, Feb 2014

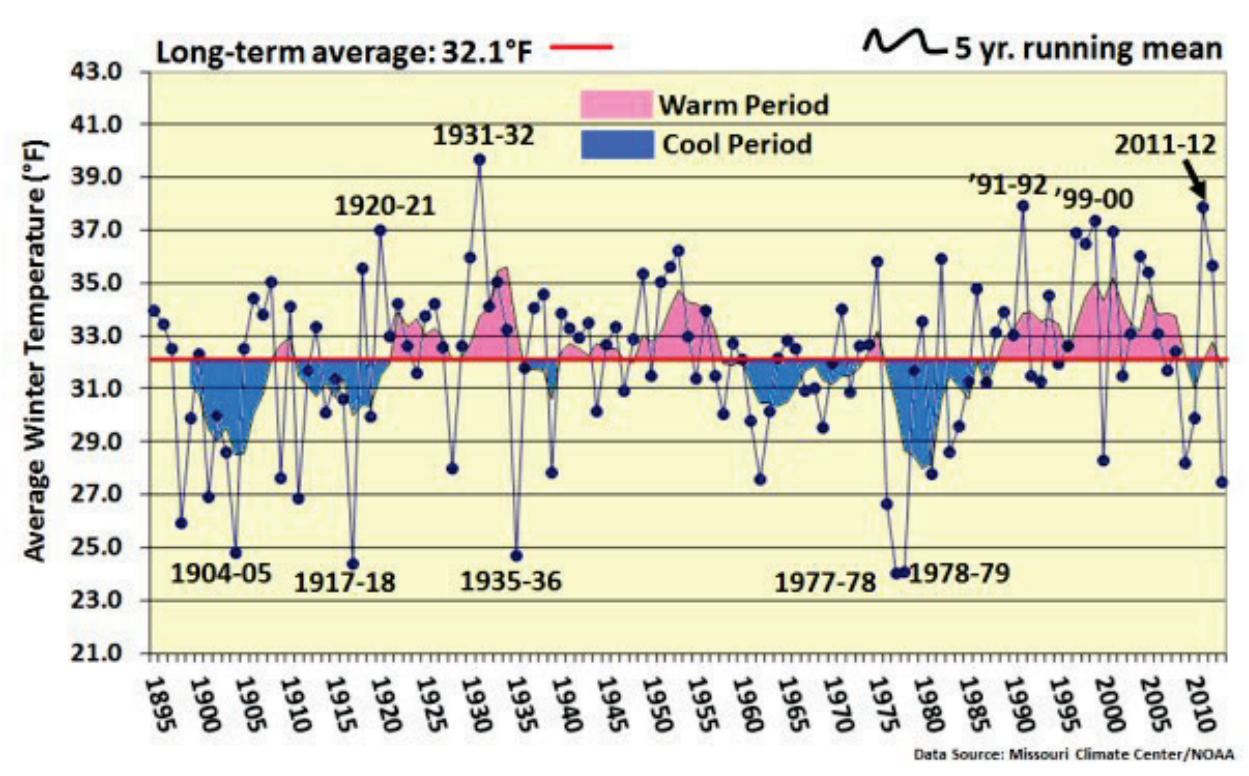

Missouri Average Summer Temperature

(Jun-Jul-Aug, 1895-2014)

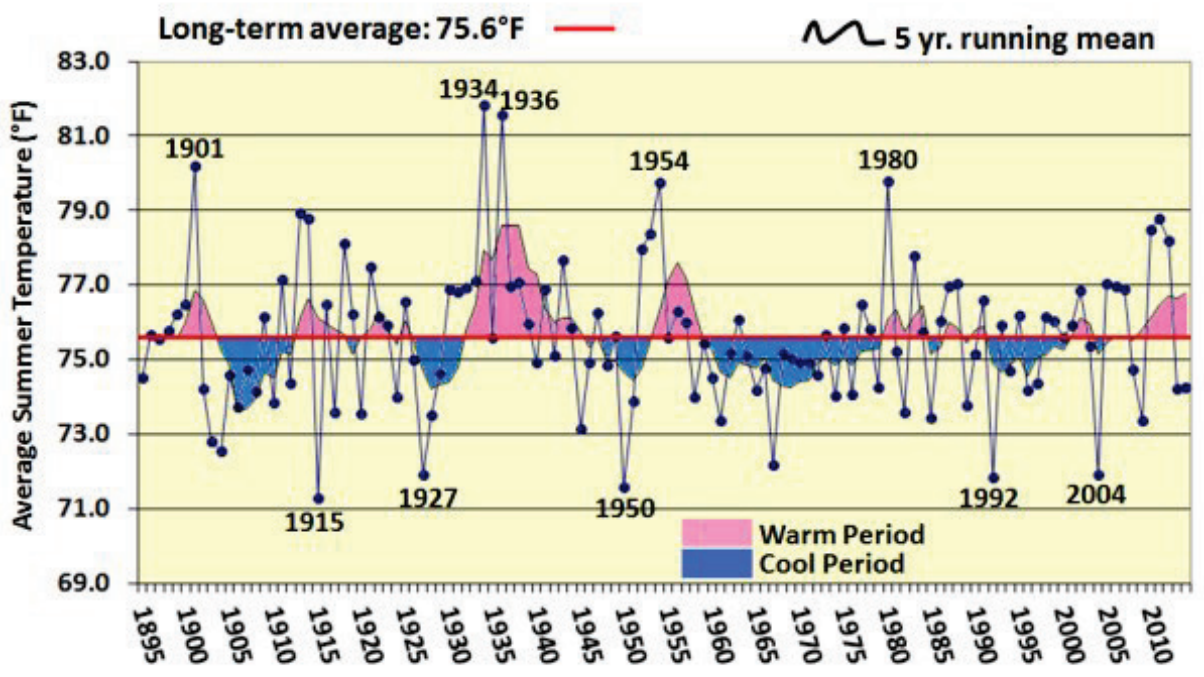


Figure 3. Missouri hypothermia mortality, 1989 to 2012.

(Source: Missouri Department of Health and Senior Services.)

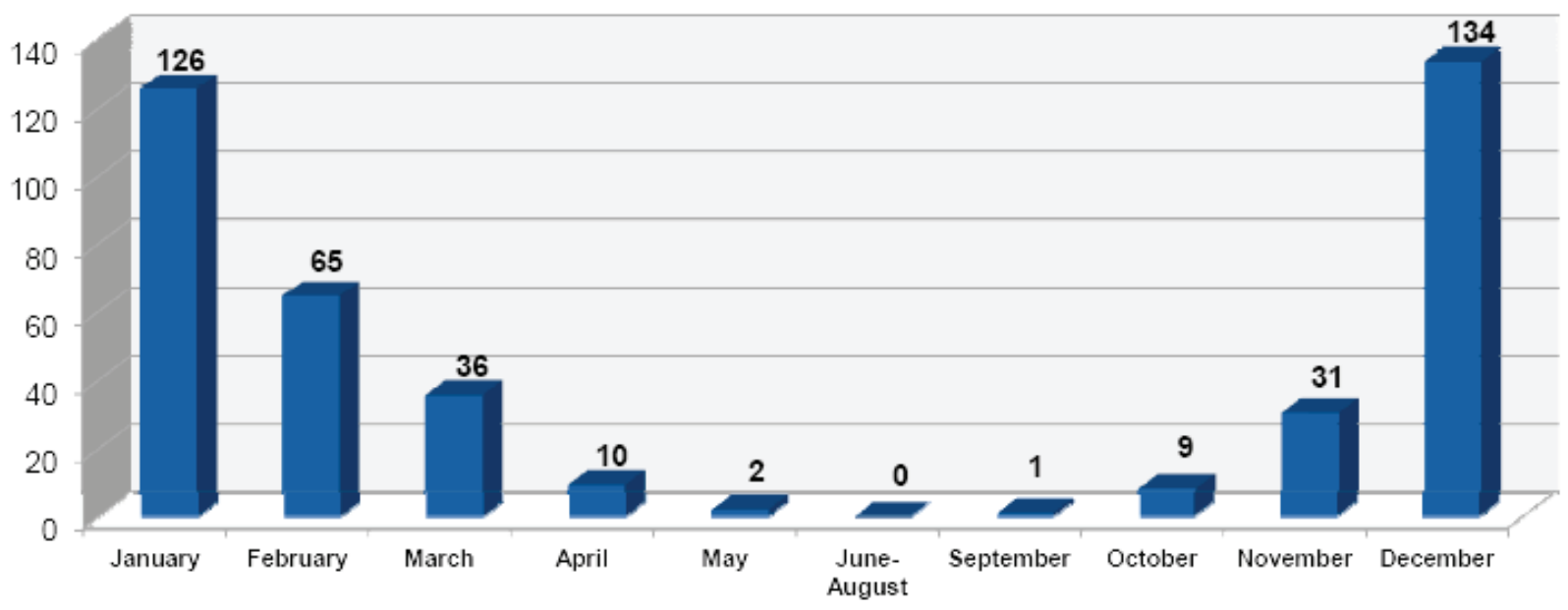

Figure 4. Hypothermia related deaths in winter seasons from 1979 to 2012. (Source: Missouri Department of Health and Senior Services.)

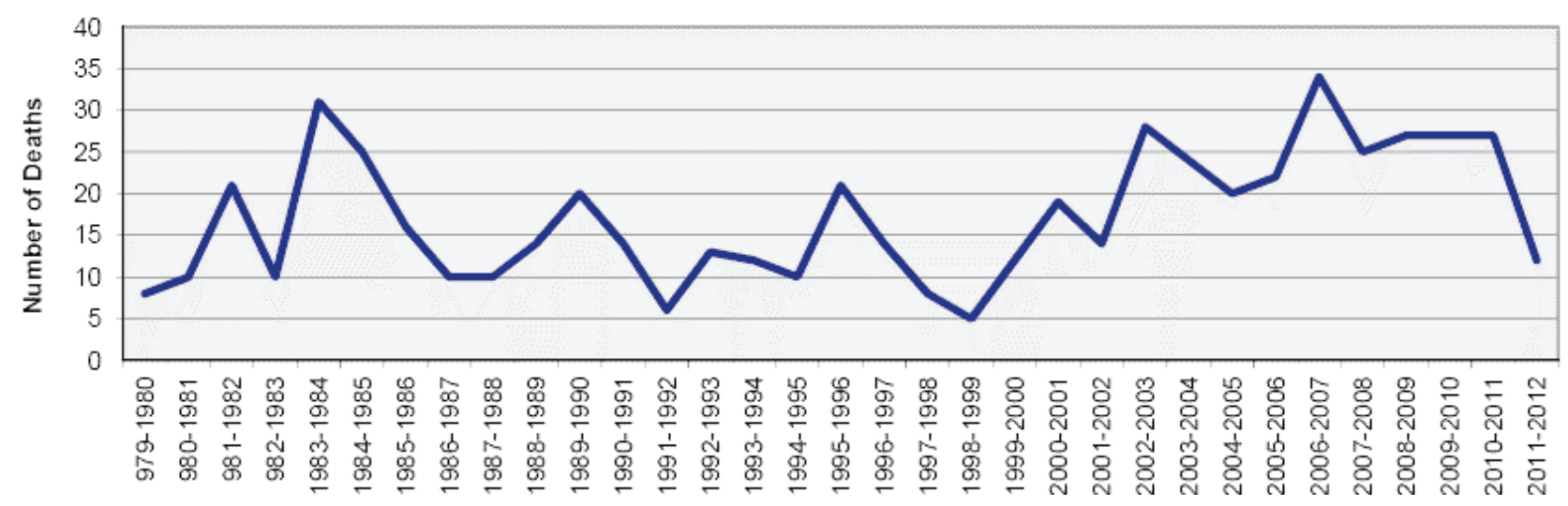

Heat also can have severe health impacts. From $30{ }^{\circ} \mathrm{C}$ (or $86{ }^{\circ} \mathrm{F}$ ), people can begin having heat-related side effects. The effect may be fatigue, heat cramps, or heatstroke. Prolonged high temperature exposure can cause exhaustion due to loss of water and/or salt diminution and in worst-case scenarios, death. On August 14, 1936 Kansas City suffered approximately 5 , 000 deaths, from a summer heat wave that reach $113^{\circ} \mathrm{F}$. The heat wave lasted 16 consecutive days with temperatures higher than $100{ }^{\circ} \mathrm{F}$. Extreme heat waves have occurred in the U.S. in 1936, 1953, 1954, 1955, and 1966 with Missouri having a higher mortality rate than other states (Bridger et al. 1976). Also, in 1980, a heat wave affected the southern plains and the Midwestern U.S. Kansas, Missouri, suffered a seventeen day continuous heat wave. What would be the consequences on Fort Leonard Wood today with a repeat of one of these historic hot summers? 
The National Oceanic and Atmospheric Administration (NOAA) National Weather Service registered average historical temperature ranges and extremes from the Fort Leonard Wood weather station from 1960 to 2014. These are shown in Figure 5. This image shows annual temperature trends from January through December. The solid blue and red lines show the average daily minimum and maximum temperatures, respectively. Half of the daily minimum temperatures fall within the darker blue band and 80\% of these within the lighter blue band. Similarly, $50 \%$ of the daily high temperatures fall within the red band and $80 \%$ of these values fall within the light red band. The jagged lighter red and blue lines represent daily record high and low values. Note that winter temperatures are much more variable than the more predictable summer temperatures. Also note that the maximum and minimum recorded daily temperatures. Imagine connecting the highest highs to identify what new high possibilities exist for intervening days.

Figure 5. Historic temperature ranges and extremes from Fort Leonard Wood weather station. (Source: National Weather service; image from Weatherspark.com.)

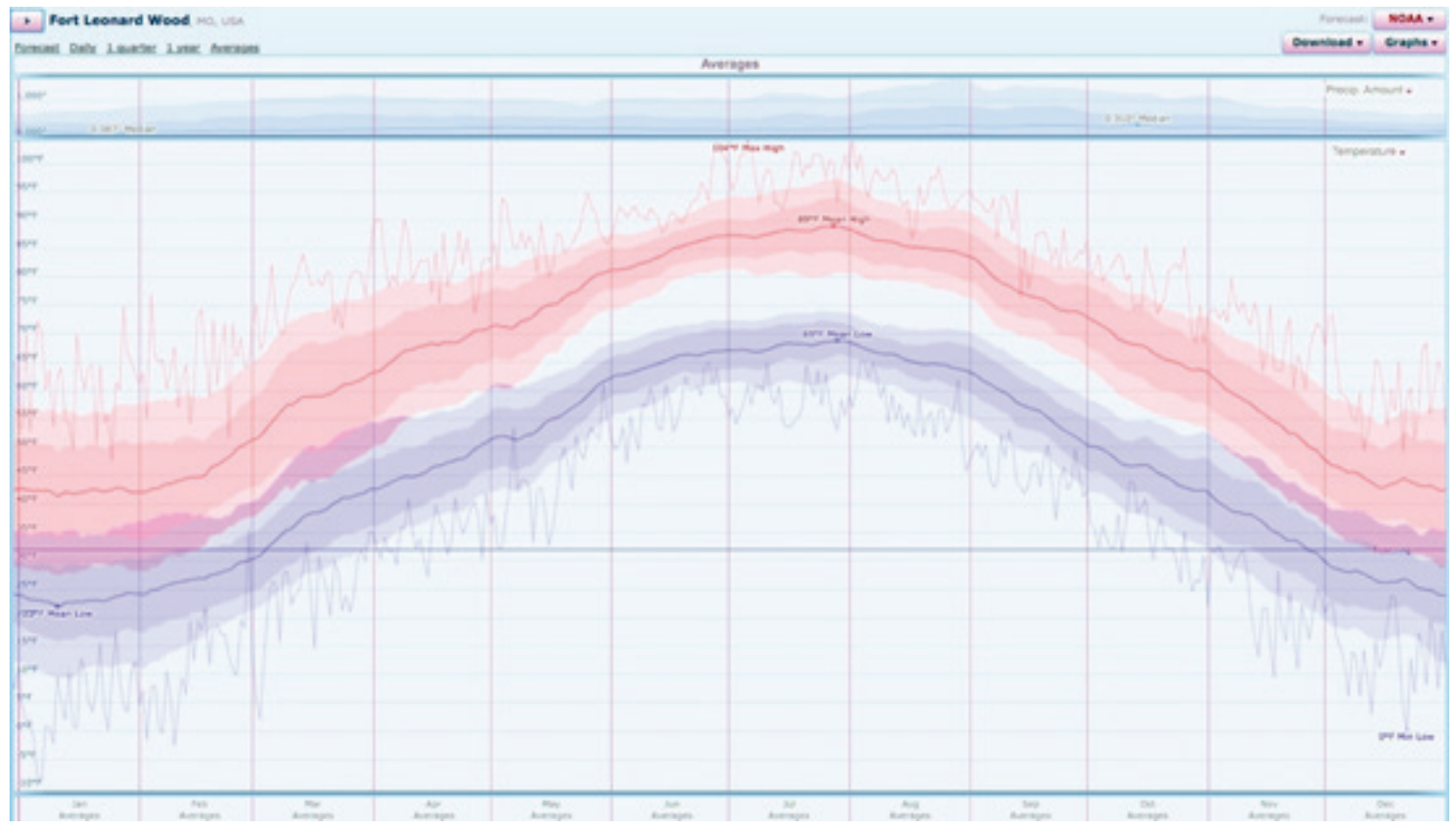

While the above data includes three months each for summer and winter, individual storms can be devastating. The NOAA storm events database only has records of severe storms by county since 1995. This removes one of the key ways for finding black swan events which is to analyze long periods of data. According to this database, on January 1, 2001 and December 12, 2010, extreme cold weather affected all of the counties within the study 
area. This caused failure of many water mains, roof leakage, and hazardous roads. For both cases, temperatures were $10{ }^{\circ} \mathrm{F}$ to $20{ }^{\circ} \mathrm{F}$ below normal.

The same approach was done to find extreme heat events with periods of high temperatures. From 1999 to 2012, a total of nine events were recorded. The summer of 1999 (July to August) had a period of excessive heat that affected the region of interest. July 23, 1999 heat index values were from 105 to $115{ }^{\circ} \mathrm{F}$ and because of this, six mortalities in nearby counties occurred. Other high temperature events recorded in this database were dated August 27, 2000; November 1, 2000; July 17, 2001; and June thru August, 2012.

The probabilities of having extreme weather events are high because it is already characteristic of the region. Heat waves are very common in the region and these are also being affected by climate change. The pattern for the Midwest moves towards more notable extreme temperatures at the end of this century. Therefore, another topic that must be considered is the increase of the extreme temperatures recorded $\left(-40^{\circ} \mathrm{F}\right.$ and $\left.118^{\circ} \mathrm{F}\right)$ and length of these events due to climate change.

\subsection{Planning measures}

Based on the regional historic temperatures, it is expected that Fort Leonard Wood already has related risk management procedures. Nonetheless, several recommendations will be mentioned to protect personnel, equipment, and infrastructure. It is important during extreme cold or extreme heat scenarios that the buildings have good insulation. For extreme cold events, the insulation can hold the heat, reducing its loss and providing savings by decreasing energy demand requirements. A parameter, called $\mathrm{R}$-value is the tool used to measure the level of insulation. A higher value of R means better thermal insulation U.S. Department of Energy (DoE). The North American Insulation Manufacturers Association (NAIMA) developed a map of the U.S. climate zones. To do so, they combined recommendations from the International Energy Conservation Code (IECC) and the DoE. According to the climatic characteristics, the regions are divided into 5 zones. Figure 6 shows the recommended insulation levels of fiberglass, slag wool insulation, and rock wool (NAIMA). Southern Missouri is in Zone 4, characterized as needing both cooling and heating due to its high climate variability. The corresponding Zone 4 description is detailed in Table 2. The R-value of insulation or maximum thermal performance can also be influenced by how it was installed (DoE). An important rec- 
ommendation would be to verify if Fort Leonard Wood is complying with the recommended R-values of insulation per building component. An even better improvement for Fort Leonard Wood would be to upgrade existing insulation to a higher R-value in order to reduce energy use.

Table 3 details some of the types of insulation, their materials, and their corresponding applications (U.S. DoE).

Figure 6. Characterization of climate zones for the recommended levels of insulation.(Source: North American Insulation Manufacturers Association.)

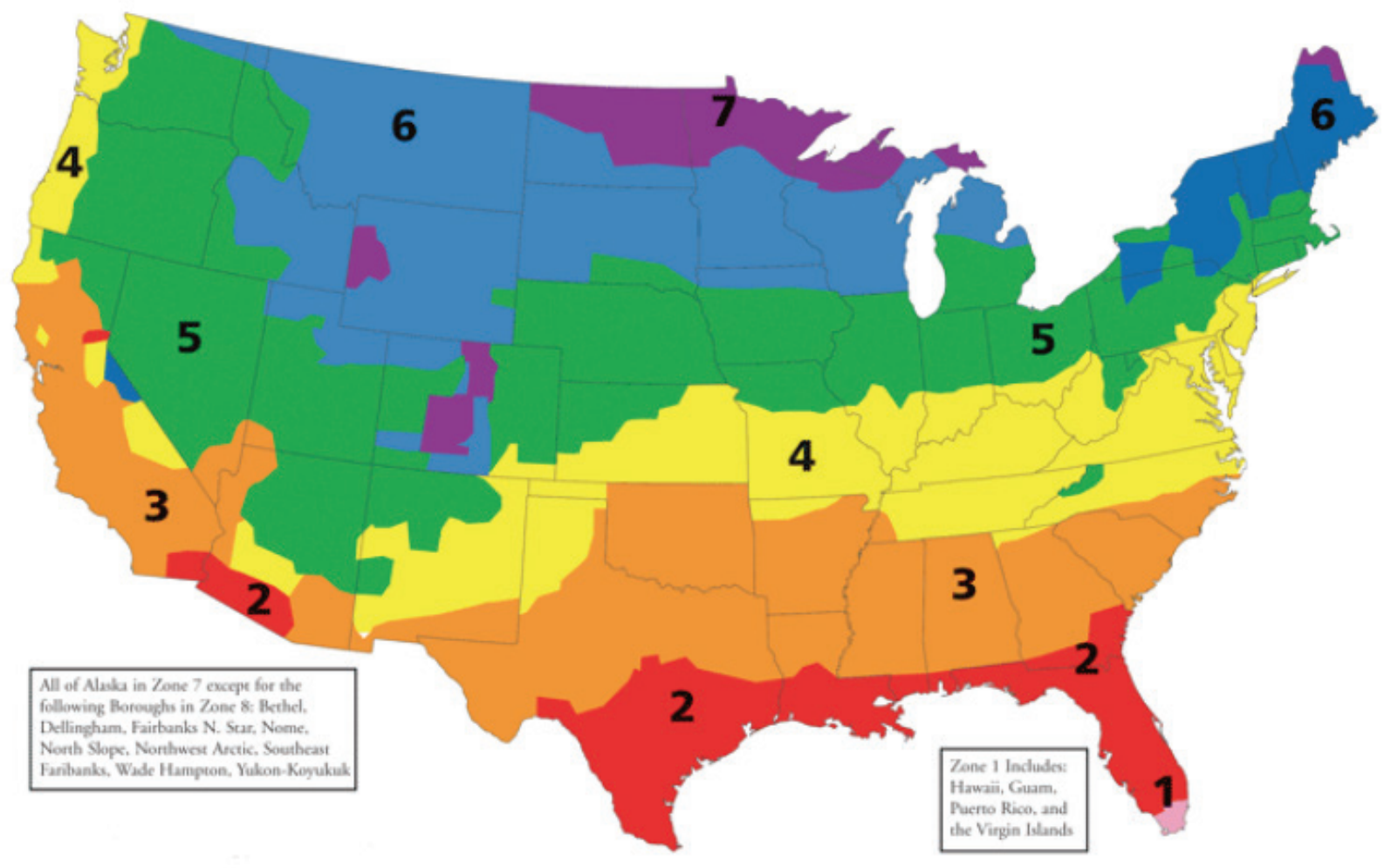

Table 2. Recommended levels of fiberglass, rock wool, and slag wool insulation for Zone 4. (Source: North American Insulation Manufacturers Association.)

\begin{tabular}{|c|c|c|c|c|c|c|}
\hline Zone & $\begin{array}{c}\text { Heating } \\
\text { System }\end{array}$ & Attic & $\begin{array}{c}\text { Cathedral } \\
\text { Ceiling }\end{array}$ & \multicolumn{2}{|c|}{ Wall } & Floor \\
\hline \multirow{2}{*}{4} & $\begin{array}{c}\text { Gas, oil, } \\
\text { heat pump }\end{array}$ & & & & R 2.5 to R6 & \\
\cline { 2 - 2 } & $\begin{array}{c}\text { Electric } \\
\text { furnace }\end{array}$ & R38 to R60 & R30 to R38 & R13 to R15 & R5 to R6 & R25 to R30 \\
\hline
\end{tabular}


Table 3. Insulation type, materials, and applications. (Source: U.S. DoE.)

\begin{tabular}{|l|l|l|}
\hline \multicolumn{1}{|c|}{ Type } & \multicolumn{1}{|c|}{ Materials } & \multicolumn{1}{c|}{ Application } \\
\hline $\begin{array}{l}\text { Blanket: batts } \\
\text { and rolls }\end{array}$ & $\begin{array}{l}\text { Fiberglass, mineral wool, } \\
\text { plastic fibers, natural fibers. }\end{array}$ & $\begin{array}{l}\text { Floors, ceilings, unfinished } \\
\text { walls. }\end{array}$ \\
\hline $\begin{array}{l}\text { Concrete block } \\
\text { insulator }\end{array}$ & Foam board. & $\begin{array}{l}\text { Unfinished wall, foundation } \\
\text { walls. }\end{array}$ \\
\hline $\begin{array}{l}\text { Insulating } \\
\text { concrete blocks }\end{array}$ & $\begin{array}{l}\text { Foam beads or air added to } \\
\text { concrete mix. }\end{array}$ & New walls. \\
\hline $\begin{array}{l}\text { Foam board or } \\
\text { rigid foam }\end{array}$ & $\begin{array}{l}\text { Polystyrene, polyisocyanurate, } \\
\text { polyurethane. }\end{array}$ & $\begin{array}{l}\text { Unfinished wall, foundation } \\
\text { walls, floors, ceilings. }\end{array}$ \\
\hline $\begin{array}{l}\text { Loose-fill and } \\
\text { blown-in }\end{array}$ & $\begin{array}{l}\text { Cellulose, fiberglass, mineral } \\
\text { wool. }\end{array}$ & Existing walls, attic floors. \\
\hline $\begin{array}{l}\text { Reflective system } \\
\text { Cardboard, plastic film }\end{array}$ & $\begin{array}{l}\text { Unfinished floors, walls, and } \\
\text { ceilings }\end{array}$ \\
\hline $\begin{array}{l}\text { Rigid fibrous, fiber } \\
\text { insulation }\end{array}$ & Fiberglass, mineral wool & $\begin{array}{l}\text { Places that can withstand high } \\
\text { temperatures, ducts in } \\
\text { unconditioned spaces }\end{array}$ \\
\hline $\begin{array}{l}\text { Sprayed foam and } \\
\text { foamed-in-place }\end{array}$ & $\begin{array}{l}\text { Cementitious, polyurethane, } \\
\text { polysocyanurate, phenolic. }\end{array}$ & $\begin{array}{l}\text { Existing wall, cavities in new } \\
\text { wall, unfinished attic floors }\end{array}$ \\
\hline $\begin{array}{l}\text { Structural } \\
\text { isolated panels }\end{array}$ & $\begin{array}{l}\text { Foam board, liquid foam } \\
\text { insulation core, straw core } \\
\text { insulation }\end{array}$ & New constructions \\
\hline
\end{tabular}

There is another way of obtaining an R-value estimate, developed by the Oak Ridge National Laboratory and the DoE, that depends on the heating system. This estimate takes into account the location and type of fuel used for heating: natural gas, fuel oil, or propane.

That takes us to another important point. The point is to have other heating and cooling capabilities in the buildings as a precaution if one fails. A consideration would be solar panels. Solar heating avoids carbon emissions and are efficient to implement.

Prolonged heat exposure can cause fatigue, heat cramps, heatstroke, and possibly death. For hot temperatures, air-conditioning is necessary. First, it is recommended to do an analysis of the heating and cooling load for estimating the sizes for an air conditioning system. An alternative would be to verify if the current air conditioners comply with the minimum load calculation design according to the Air Conditioning Contractors of America (ACCA) or the American Society of Heating, Refrigerating, and Air Conditioning Engineers (ASHRAE). Air conditioning is usually powered by elec- 
tricity. For tackling extreme hot weather events, part of the resilience management technique would be to have a combination of solar powered and electric air conditioning. Solar air conditioned cooling could come from the installation of solar electric panels on a roof. This is not as simple as it sounds, since it requires a lot of panels to absorb the required amount of energy. A combination of energy efficiency upgrades (such as insulation), and purchase of the lowest consuming electric air conditioning units is desired environmental savings. Another solar powered alternative is evaporative coolers. This would work best in very dry regions.

Another option that could be implemented would be to add green roofs within the installation. Green roofs reduce the amount of heat in a building by increasing the insulation, so this could be another way to aid preparation. This alternative has already been implemented on other military installations, including at the Installation Transportation Deployment Support Area at Fort Bragg.

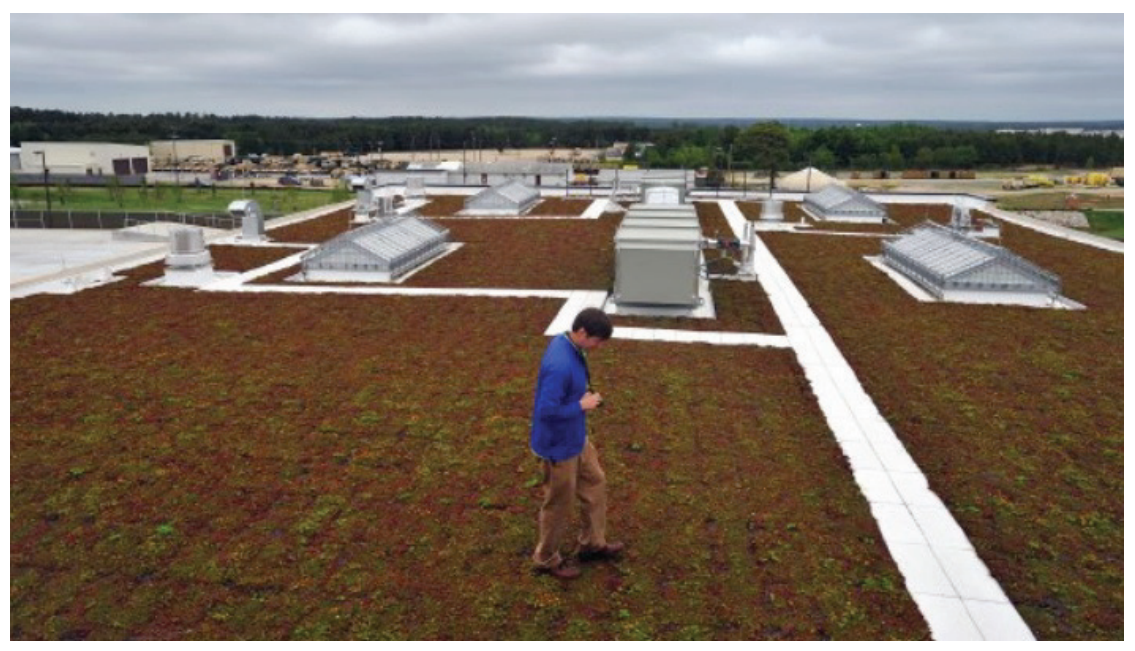

Figure 7. Green roof at the Transportation Deployment support area at Fort Bragg. (Source: LiveRoof Brand webpage.) 


\section{Severe Wind Events}

\subsection{Potential events}

In general, the number of tornadoes in the U.S. has increased during the last 50 years. Due to Missouri's geography, many wind related disasters have occurred in the region. There are several sources for wind zone standards, such as these maintained by U.S. Department of Housing Urban Development (HUD), Federal Emergency Management Agency (FEMA) and the National Fire Protection Association (NFPA). According to FEMA Standards shown in Figure 8, Missouri is located in Zone 4 that could have tornado winds up to $250 \mathrm{mph}$. A tornado is categorized based on the estimated wind speed and severity of the damage.

Figure 8. Maximum wind velocities and corresponding zones in the U.S. according to FEMA standards category and using ASCE 7-05. (Source: FEMA.)

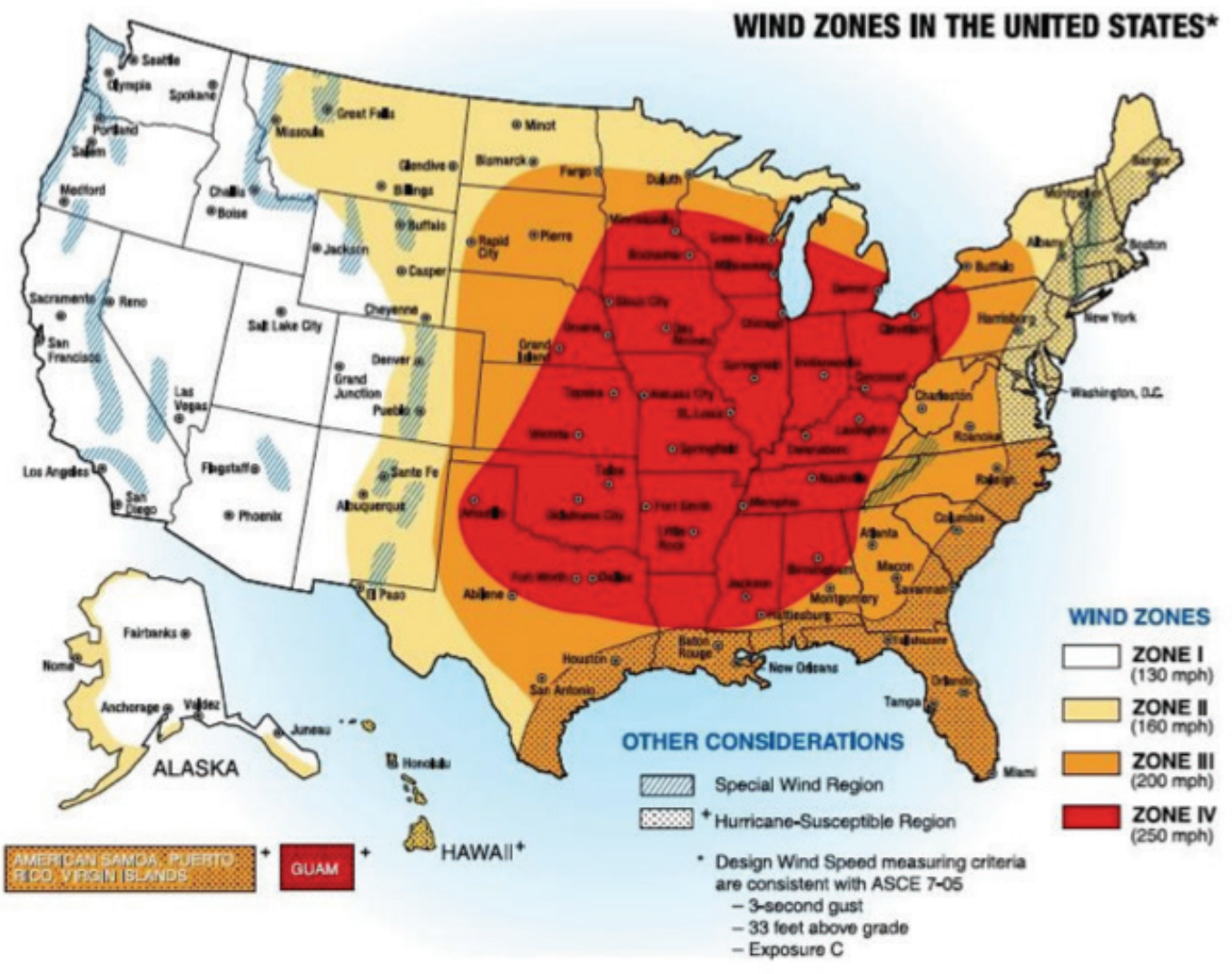


Tornadoes are common in Missouri all year long, with greatest incidences between March and June. According to the Missouri Storm Aware page, six of the deadliest tornadoes in the U.S. have occurred in this state. The Missouri Climate Center estimates that approximately thirty tornadoes occur yearly through the state. Some historic Missouri tornado events from 1990 to 2000 are shown in Table 4. On March 18, 1925 a tornado later described as F5, hit Missouri, Illinois, and Indiana (therefore named the TriState tornado), through a 219 mile trajectory, killing approximately 695 people. One of the recent deadliest tornadoes was on May 22, 2011. Called the Joplin tornado, a total of 161 deaths were reported from this EF5 category tornado with maximum winds of $250 \mathrm{mph}$. The estimated route of the Joplin tornado is shown in Figure 9. It destroyed everything within a sixmile trajectory.

Table 4. Extreme Missouri tornado events. (Source: Missouri Climate Center.)

\begin{tabular}{|l|c|}
\hline \multicolumn{1}{|c|}{ Event } & Date \\
\hline Tri-State Tornado. 695 killed (9 in Missouri) and 2027 injured. & March 18, 1925 \\
\hline $\begin{array}{l}\text { Poplar Bluff. Type F4, trajectory of 3 minutes. 93 killed. } \\
\text { \$2 M in damages }\end{array}$ & May 9, 1927 \\
\hline $\begin{array}{l}\text { St. Louis. Type F4, St. Louis tornado, 72 killed. } \\
\text { \$22 M in damages. }\end{array}$ & September 29, 1927 \\
\hline A total of 13 tornadoes reported. & March 1938 \\
\hline A total of 13 tornadoes reported in Missouri. & 1967 \\
\hline
\end{tabular}


Figure 9. Estimated trajectory and impact area of the Joplin tornado in Missouri on May 22, 2011. (Source: U.S. Army Corps of Engineers, Kansas City District.)

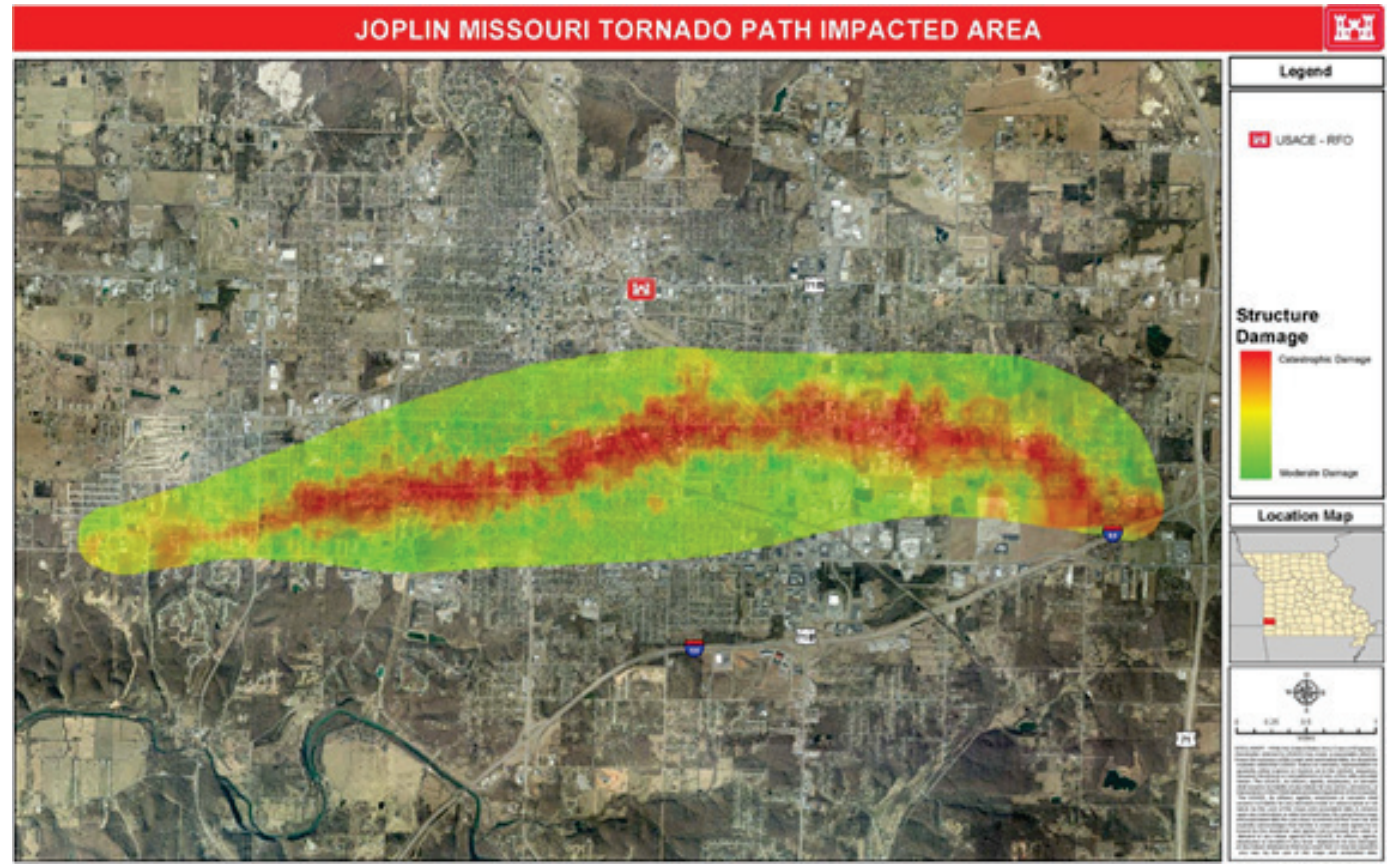

The NOAA storm events database was implemented to obtain more detailed information about tornadoes felt at our AOI. According to this source, Camden has experienced 16 tornadoes (total recorded) with magnitudes that ranged from F1 to F3 from 1954 to 2008. A summary of tornado history for the region of interest is shown in Table 5 .

Table 5. Area of Interest tornado history summary from 1950 to 2012. (Source: Storm Events Database.)

\begin{tabular}{|l|c|c|c|c|c|c|}
\hline \multicolumn{1}{|c|}{ County } & Year Range & $\begin{array}{c}\text { Magnitude } \\
\text { Range }\end{array}$ & Deaths & Injured & $\begin{array}{c}\text { Estimated } \\
\text { Property } \\
\text { Damage }\end{array}$ & $\begin{array}{c}\text { Estimated } \\
\text { Crop } \\
\text { Damage }\end{array}$ \\
\hline Camden & $1954-2008$ & F0 to F3 & 4 & 30 & $7.933 \mathrm{M}$ & $1 \mathrm{M}$ \\
\hline Dent & $1957-2012$ & F0 to F3 & 2 & 4 & $612.75 \mathrm{~K}$ & $5 \mathrm{~K}$ \\
\hline Laclede & $1960-2012$ & F0 to F3 & 0 & 23 & $14.828 \mathrm{M}$ & 0 \\
\hline Maries & $1957-2008$ & F0 to F2 & 0 & 1 & $5.375 \mathrm{M}$ & 0 \\
\hline Miller & $1966-2009$ & F0 to F2 & 0 & 6 & $3.86 \mathrm{M}$ & 0 \\
\hline Phelps & $1951-2012$ & F0 to E3 & 2 & 10 & $9.308 \mathrm{M}$ & 0 \\
\hline Pulaski & $1950-2010$ & F0 to F3 & 0 & 19 & $101.86 \mathrm{M}$ & 0 \\
\hline Texas & $1953-2009$ & F0 to F4 & 2 & 17 & $9.160 \mathrm{M}$ & 0 \\
\hline Wright & $1959-2009$ & F0 to F4 & 0 & 12 & $6.03 \mathrm{M}$ & 0 \\
\hline
\end{tabular}


Tornado data for black swan analysis can also be obtained from the Tornado History Project webpage. This source illustrates the path followed by each tornado and uses data retrieved from the Storm Prediction Center's historical tornado data file (from 1950 to 2014). Figure 10 shows part of Missouri's tornado history, intensities, and paths.

Additionally, high winds due to thunderstorms or combination of low pressure and cold fronts seem to be common in this area. Winds of 48 to 79 knots have been experienced in the AOI. On May 4, 1996, 79 knot thunderstorm winds were the cause of downed trees near Fort Leonard Wood.

Figure 10. Tornado intensities and path near Fort Leonard Wood, Missouri. (Source: Tornado History Project webpage.)

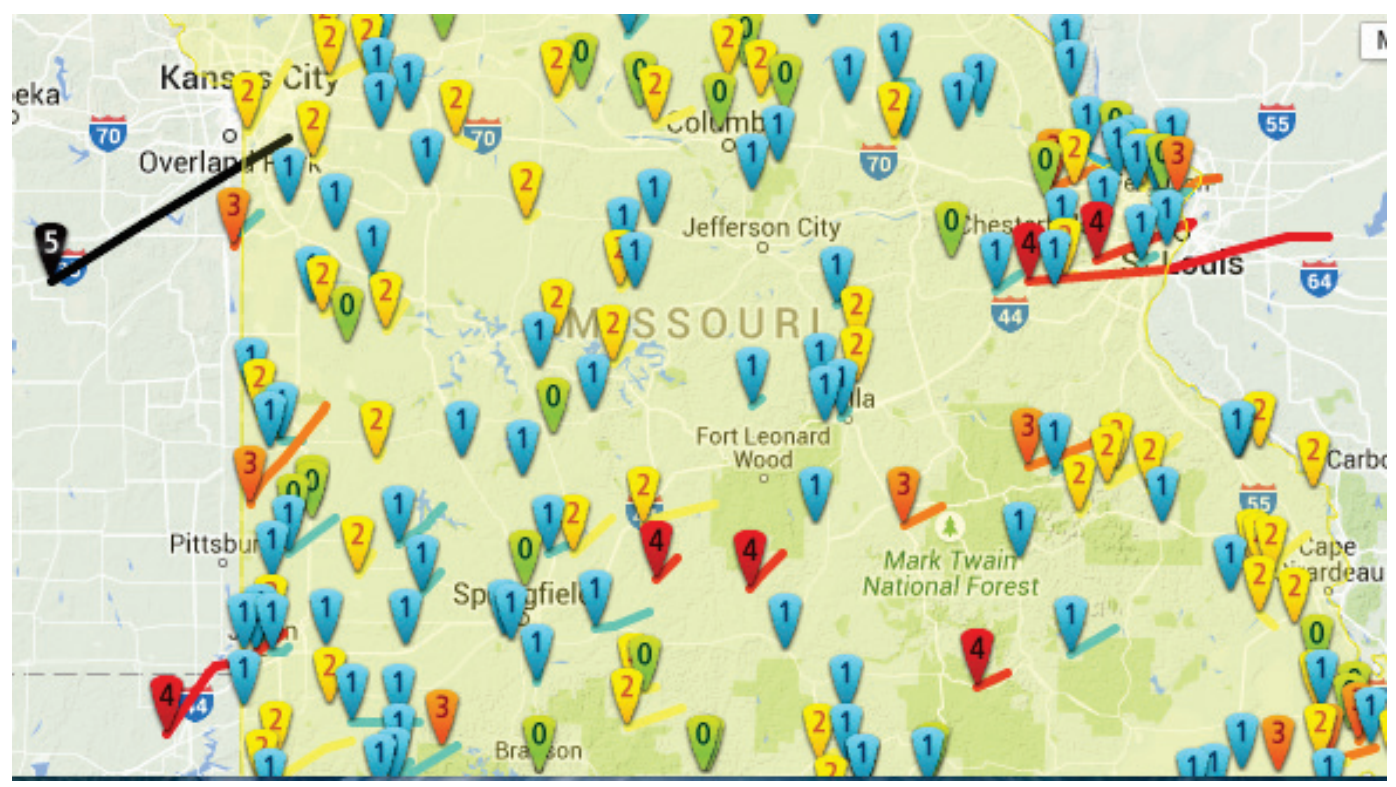

In general, the AOI has experience tornadoes up to F4 scale (in the counties of Texas and Wright). Because of the high numbers of tornadoes in the area, this event is one that should be already in Fort Leonard Wood's Risk Management Plan. However, the plan should be checked to see if it considers higher magnitude tornadoes, up to $\mathrm{EF} 5$, and their possible impacts.

\subsection{Planning measures}

Although high category tornadoes of $\mathrm{EF}_{4}$ and $\mathrm{EF}_{5}$ are less probable, the military installation might establish plans that prepare for tornadoes with wind higher than $200 \mathrm{mph}$. Fort Leonard Wood might consider structures or shelters that can withstand those higher wind impacts, following the In- 
ternational Code Council (ICC) 500 and/or the FEMA storm shelter standards. Figure 11 shows the construction of a tornado safe room in Sioux City, Iowa. This safe room includes steel bar reinforcement on walls and ceiling, foam walls filled with cement, and a door that can withstand high wind pressure and objects carried by the wind. The structure can be added either outside or inside (i.e., basement, garage, etc.) an existing building or a new one. A safe room could also be underground but it must be designed to prevent water accumulation. Additionally, the safe room should be equipped with the necessary supplies such as crank-operated or battery flashlights, radio, first aid kit, dust mask, food and water, medication, whistles or air horns, etc. A safe room amidst the aftermath of a tornado is shown in Figure 12. It would also be preferable that the employees have a backpack with additional clothing, medication, water, and food in their work areas.

Figure 11. Safe room construction in Sioux City, lowa. (Source: Dave Gatley, FEMA.)

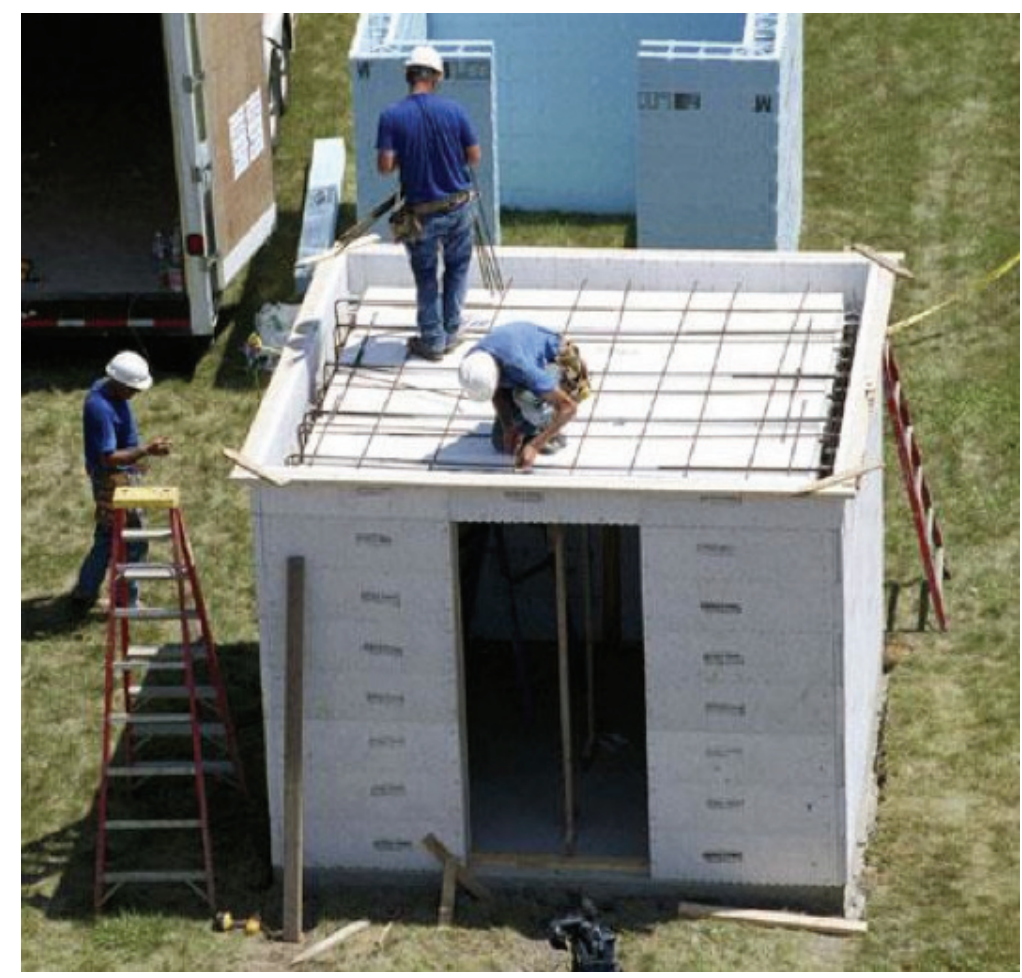


Figure 12. Safe room condition after a tornado hit Piedmont, Oklahoma. (Source: Syracuse Media Group webpage.)

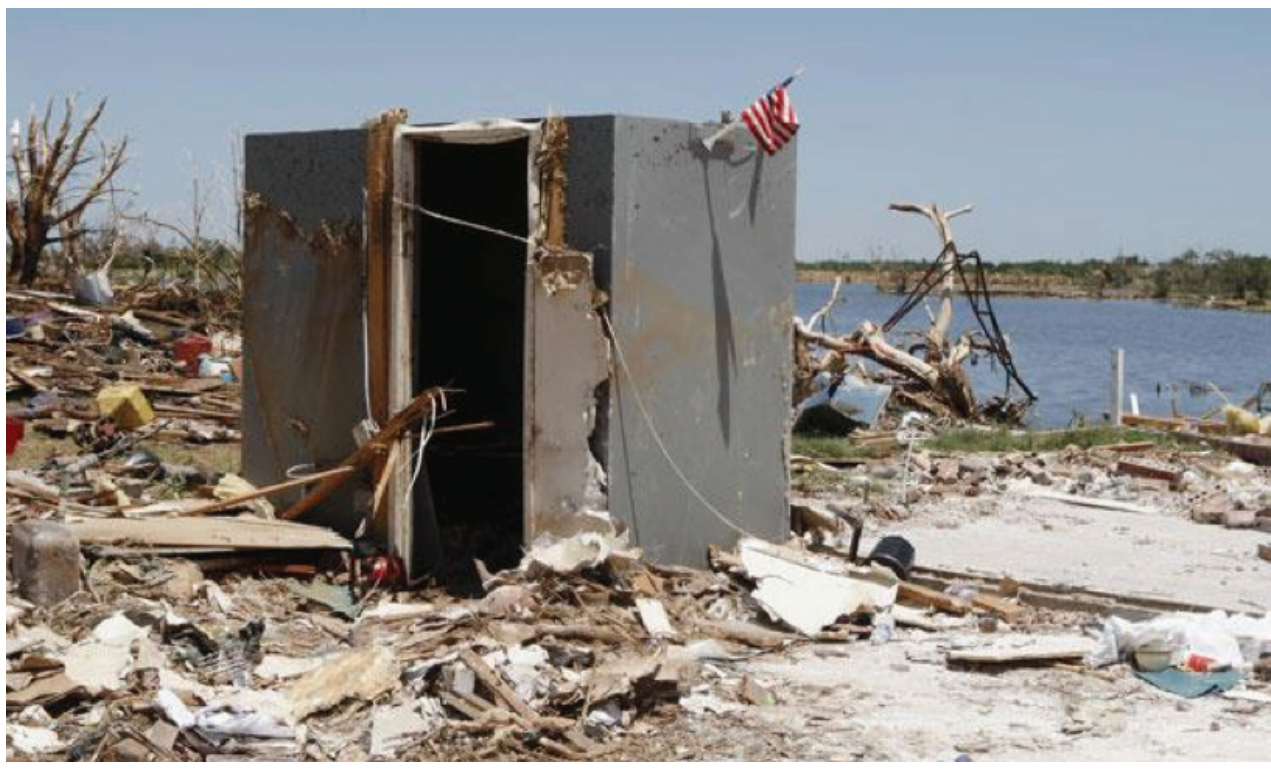

The combination of high winds and extremely low atmospheric pressures associated with tornados can easily result in the loss of roofs and the dislocation of buildings from their foundations. Fort Leonard Wood buildings could be surveyed to identify the worst conditions that could be survived. Building retrofits could be considered to more firmly anchor walls to foundations and roofs to walls. 


\section{Extreme Precipitation}

\subsection{Potential events}

The topography and location of Missouri is ideal for harsh weather event conditions, such as heavy rain and severe storms, during the entire year. A study titled Weather Variety Special Report named Springfield, Missouri, as the U.S. city with highest weather variability. The assessment took into account parameters such as diurnal temperature variations, annual temperature variations, precipitation, thunderstorms, wind, and snow. The National Weather Service made an assessment of natural hazard risks for Pulaski County up to the year 2008, briefing the important events.

According to this source, on January 8, 1997, more than six inches of snow covered central southwest and south central Missouri, causing $\$ 670 \mathrm{~K}$ in damages. Flooding is also very common in that region due to the high amounts of rainfall. Also, Pulaski County has many easily flooded low water crossings that make roads temporarily unusable. Flash floods could happen after a short period of rain of about 6 hours, depending on the intensity and the duration of the rain.

From 1996 to 2015, it is estimated that the AOI has had thirteen deaths, six persons injured, property losses of over $\$ 25 \mathrm{M}$, and $\$ 5 \mathrm{~K}$ in crop losses just from flash flood events. For example, a significant thunderstorm event with intense rainfall occurred on August 6, 2013. Up to 20 inches of rain was recorded over several days of rain, causing damage to more than 380 homes and 130 businesses in the state. Almost all of the roads in Pulaski County were impassable and suffered damage, $65 \%$ being described as major. Several roads located at Ford Leonard Wood were flooded as a result. More than a hundred people went to temporary shelters. Most of the houses that were flooded were near the Rubidoux River and Mitchell Creek. The event caused a total of two deaths in Waynesville in Pulaski County. This event affected all of the AOI.

Tropical depression and tropical storm remnants of hurricanes also do occasionally reach southern Missouri and can result in significant rainfall (Figure 13). Missouri is geographically situated where cold air from the north clashes with warm moist southern air coming off the Gulf of Mexico, generating severe thunderstorms. 
Figure 13. Tracks of historic hurricanes. (http://coast.noaa.gov/hurricanes.)

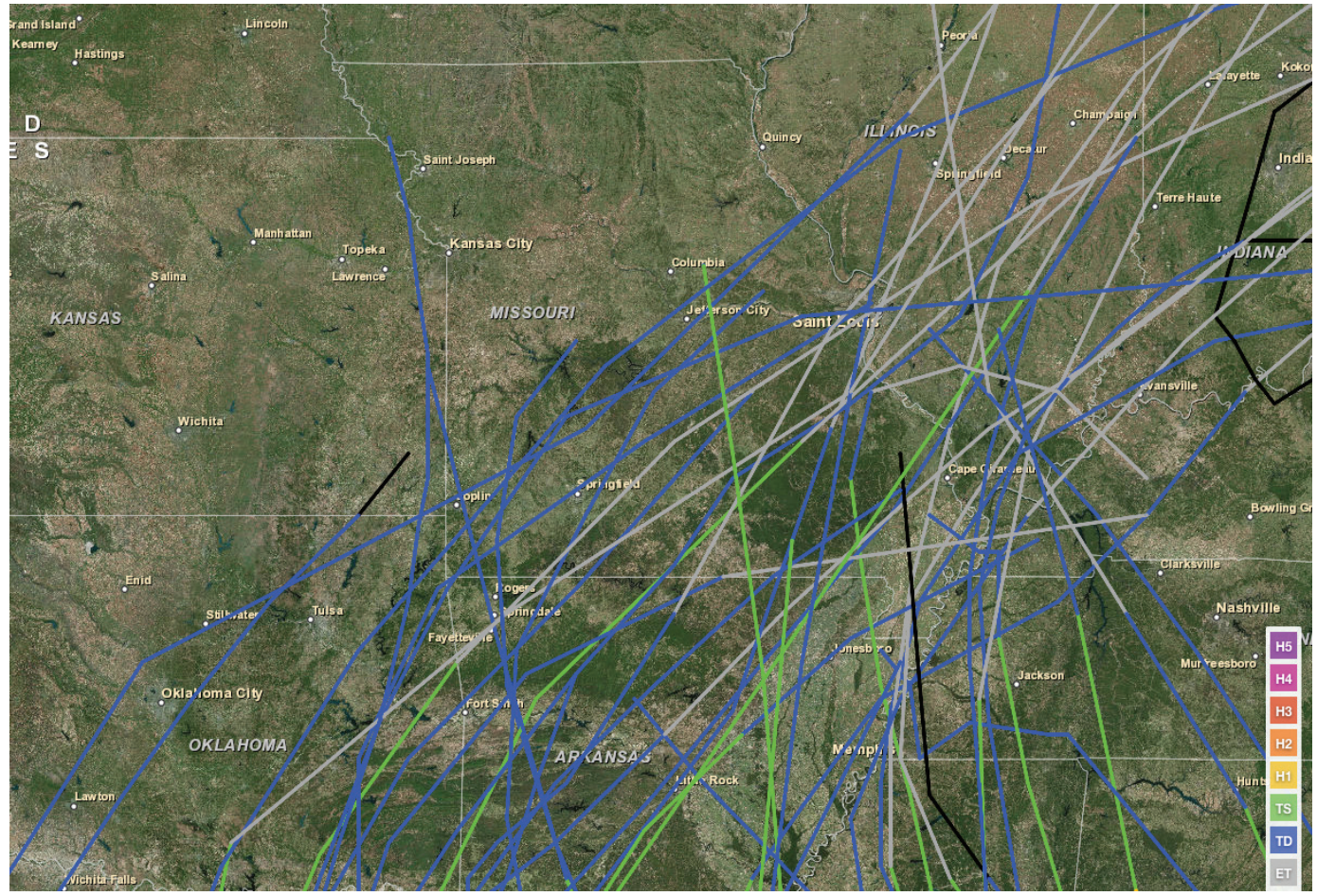

Figure 15 displays the average number of severe thunderstorm alerts by county across the U.S. The Fort Leonard Wood area is clearly accustomed to these alerts with 16 to 17 per year in the surrounding counties.

Figure 14. Average number of severe thunderstorm watches per year. (Source: http://www.spc.noaa.gov/wcm/20ysvra.png.)

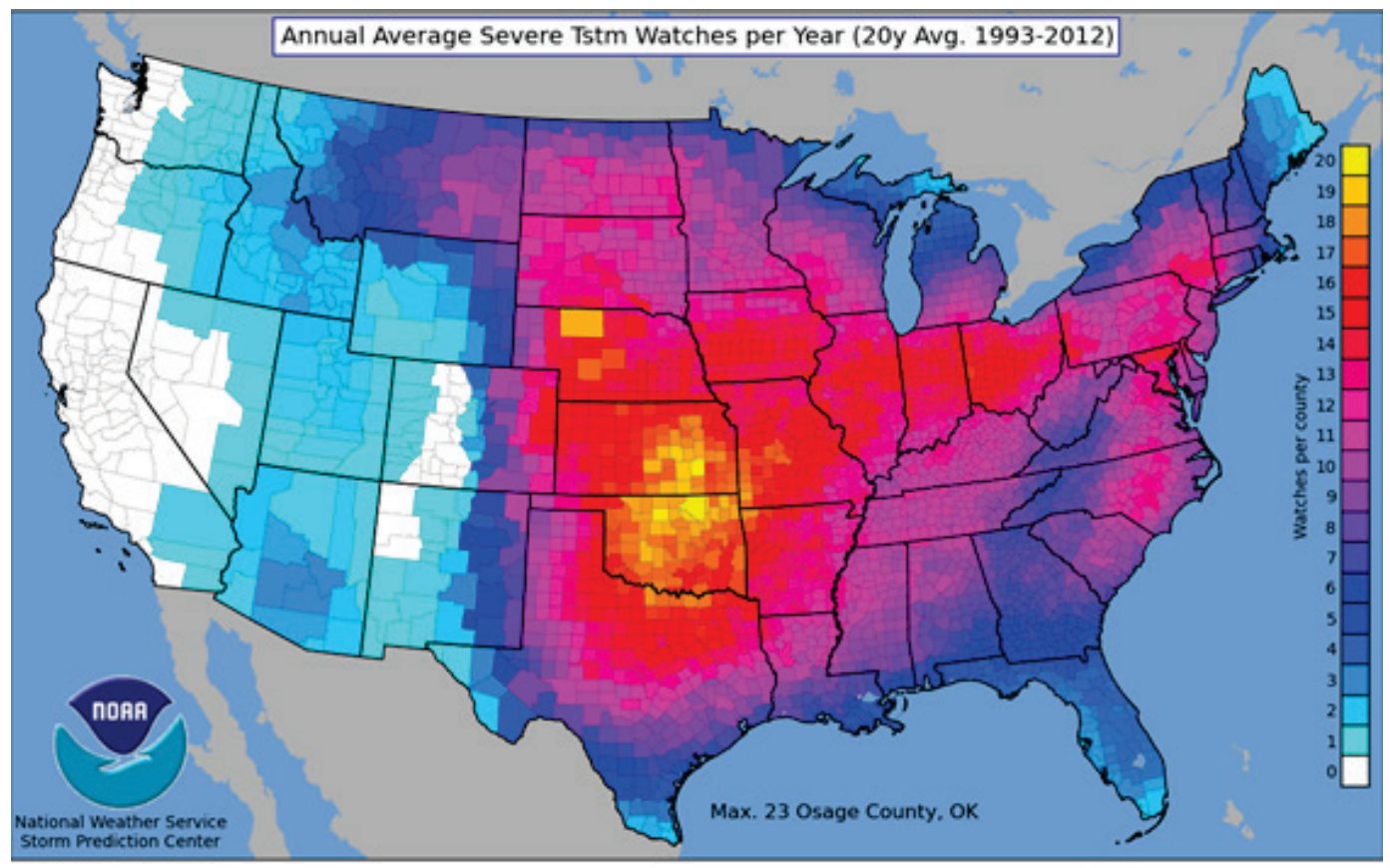


Holt, Missouri, situated only 160 miles northwest of Fort Leonard Wood holds the world record for the fastest accumulation of rainfall. In June 1947, 12 inches of rain fell in 42 minutes (Lott 1954).

Table 6. Missouri precipitation extremes. (Source: Missouri Climate Center.)

\begin{tabular}{|l|l|l|}
\hline Precipitation & Year/Months & State Average (Inches) \\
\hline Wettest Year & 2008 & 57.34 \\
\hline Driest Year & 1953 & 25.35 \\
\hline Wettest Summer & $1915(\mathrm{JJA})$ & 20.54 \\
\hline Driest Summer & 1936 (JJA) & 3.87 \\
\hline Wettest Winter & 1950 (DJF) & 11.40 \\
\hline Driest Winter & 1963 (DJF) & 2.39 \\
\hline Wettest month & 1993, September & 11.65 \\
\hline Driest month & 1986, January & 0.08 \\
\hline Wettest Year & 1957, Portageville; 92.77 \\
\hline Driest Year & 1910, Conception; 14.37 \\
\hline Wettest day & 1965, Edgerton; July 20; 18.18 \\
\hline Snowiest month & 1960, March; state average: 20.6 \\
\hline Max month snowfall & 1960, Concordia; March; 38.5 \\
\hline Deepest snow depth & 1960, Union; March 19-20; 36.0 \\
\hline World record rainfall & 1947, June 22, Holt; 12 inches in 42 minutes \\
\hline
\end{tabular}

\subsection{Planning measures}

Fort Leonard Wood is fortunate to have substantial topography that supports the rapid draining of the higher elevation levels where much of the built infrastructure exists. Nevertheless, it would be good to conduct a review of culverts, bridges, and low water crossings and anticipate water levels under potential extreme storm events. Such a study would help identify weak points where disruptions in transportation and/or potential flooding of important buildings might put the installation's missions at risk for unacceptable time periods. Retrofits could then be considered to accommodate higher water flows associated with more substantial storms.

A different approach to preparation seeks to allow for more rapid cleanup after a storm rather than complete avoidance of storm effects. For example, furnishings on the first floor of buildings that could be flooded could 
be chosen more wisely. Replace materials that absorb water and are hard to clean with hard plastics that clean easily and dry rapidly. Construct parking areas on the first floor of buildings that, if flooded, can be easily cleaned and put back to service after an event. 


\section{Drought}

\subsection{Potential events}

At the opposite extreme of flooding is drought. Meteorologists now understand that climate swings in the Midwest are driven by the El Niño Southern Oscillation (ENSO). The cool phase of this cycle (El Niño) is associated with droughts in the Midwest. Figure 15 shows a drought index for Missouri since 1895. An index of -4 is considered to be "extreme drought," and the period inclusive of 1953 and 1956 ranged from more than -3 severe drought to nearly -7. Few people now working at Fort Leonard Wood have memories of this drought and its consequences and therefore, few have likely considered the implications of such a drought if it were to occur today.

Figure 15. Historic Missouri drought index. (Source: http://mogreenstats.com/2014/02/04/missouri-wetter-than-average-in-2013.)

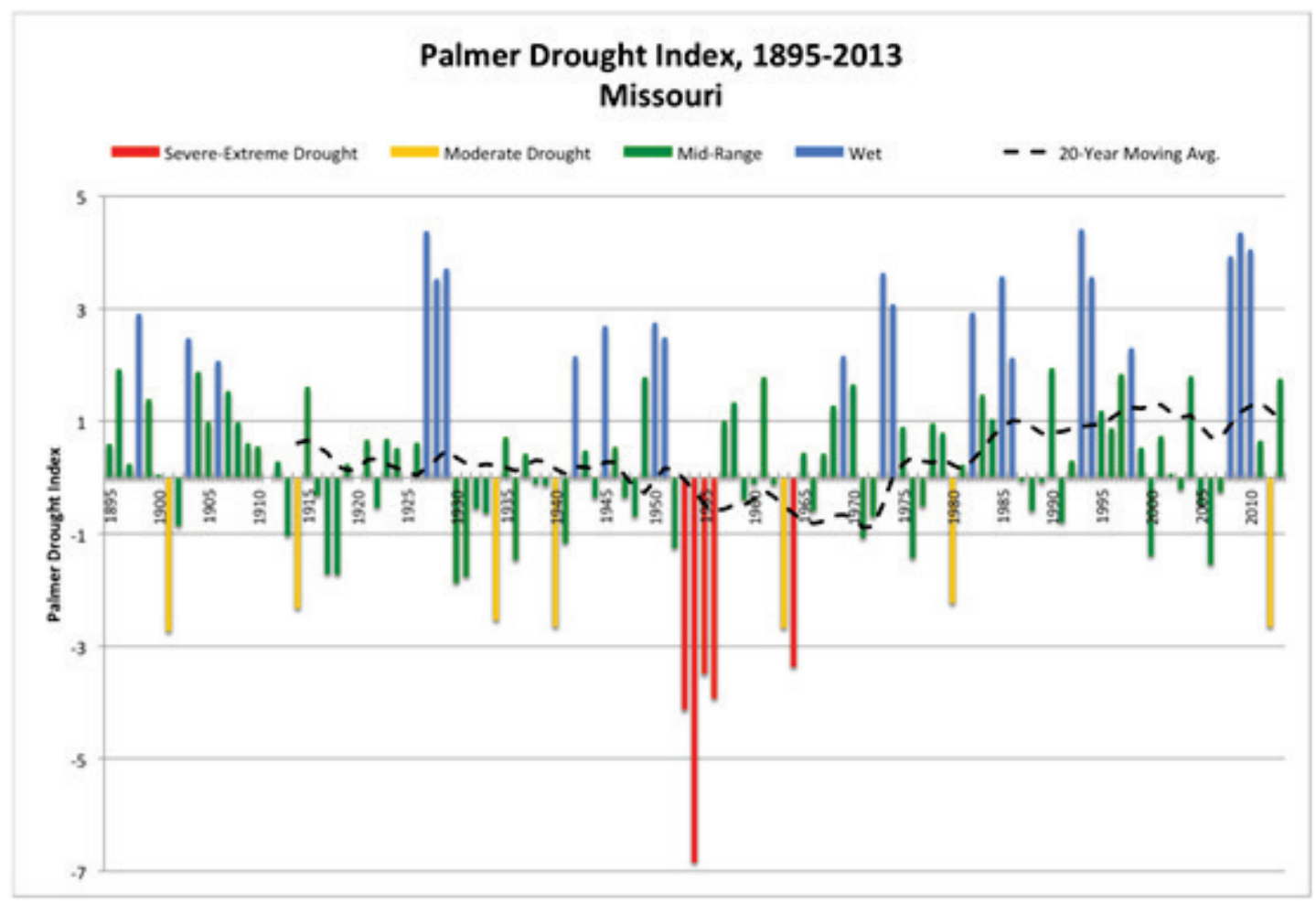

There can be many consequences of a severe drought. Mission-related impacts can include loss of training days due to fire hazards and potential loss of sufficient water resources for installation activities. Additionally, 
drought can change the forest and grassland ecosystem balances by stressing some species and opening opportunities for invasive species.

\subsection{Planning measures}

Preparation must focus on mitigating the effects of drought: municipal water availability and forest fires. Municipal water considerations should take place in consultation with regional water suppliers, cities, counties, and towns. Care must be taken to identify sufficient sources of water under a variety of water shortages. The area surrounding Fort Leonard Wood is heavily forested, creating a potentially serious situation under extreme drought. Preparing for a repeat of any conditions seen in the last forty years is not sufficient if the prolonged drought of the mid-1950s is repeated. Preparation for that level of drought will require researching the conditions and threats of that time period. Appropriate fire breaks, water access, and forest management should be developed in consultation with forest managers across the region. 


\section{Earthquake}

\subsection{Potential events}

The southeastern part of Missouri is located the most active fault system called the New Madrid Seismic Zone (NMSZ). More than 200 earthquakes occur yearly in that region but most of them are not felt by humans, according to the Missouri Department of Natural Resources. Three earthquakes have marked Missouri's history, all of which are believed to have been at least magnitude 7. The first one occurred on December 16, 1811, in the town of New Madrid. This earthquake, in addition to the damage of property, changed the topography of approximately 78,000 to 130,000 square kilometers, according to USGS. Another earthquake, with a higher magnitude was recorded in Charleston, Missouri, on January 23, 1812. The third earthquake took place on February 7, 1912, and was described as the more intense one. Elnashai, et al. (2009) estimated damage from a magnitude 7.7 New Madrid earthquake if it were to happen now. Fort Leonard Wood is outside the zone of serious direct impact.

Nowadays, earthquakes of lesser magnitudes are being felt. For example, in 2012 a magnitude 4.0 earthquake occurred at 3:58 a.m. in the southeast corner of Missouri.

The magnitude of an earthquake can be measured using the Richter scale, moment magnitude scale, or the Mercalli scale. Table 7 details the destruction levels and frequency of an earthquake, depending on the magnitude.

Table 7. Richter scale destruction level.

\begin{tabular}{|l|l|l|l|}
\hline \multicolumn{1}{|c|}{ Magnitude } & Description & \multicolumn{1}{|c|}{ How it feels } & \multicolumn{1}{c|}{ Frequency } \\
\hline Less than 2.0 & Micro & Not felt by people. & Millions per year. \\
\hline 2.0 to 2.9 & Minor & No building damages. & $\begin{array}{l}\text { More than 1 } \\
\text { million per year. }\end{array}$ \\
\hline 3.0 to 3.9 & Minor & $\begin{array}{l}\text { Often felt, may shake objects } \\
\text { inside buildings. }\end{array}$ & $\begin{array}{l}\text { More than } \\
100,000 \text { per year. }\end{array}$ \\
\hline 4.0 to 4.9 & Light & $\begin{array}{l}\text { Indoor objects shake or fell to } \\
\text { the floor. Not significant } \\
\text { damage. }\end{array}$ & $\begin{array}{l}10,000 \text { to 15,000 } \\
\text { per year. }\end{array}$ \\
\hline 5.0 to 5.9 & Moderate & $\begin{array}{l}\text { Extensive damage to buildings } \\
\text { not designed correctly. }\end{array}$ & $\begin{array}{l}1,000 \text { to 1,500 } \\
\text { per year. }\end{array}$ \\
\hline 6.0 to 6.9 & Strong & Can cause damage up to & 100 to 1500 per \\
\hline
\end{tabular}




\begin{tabular}{|c|c|c|c|}
\hline Magnitude & Description & How it feels & Frequency \\
\hline & & $\begin{array}{l}\text { about } 160 \text { kilometers across } \\
\text { in populated areas. }\end{array}$ & year. \\
\hline 7.0 to 7.9 & Major & $\begin{array}{l}\text { Widespread damage in most } \\
\text { areas. }\end{array}$ & 10 to 20 per year. \\
\hline 8.0 to 8.9 & Great & $\begin{array}{l}\text { Severe damage to several } \\
\text { hundred kilometers across. }\end{array}$ & 1 per year \\
\hline 9.0 to 9.9 & Great & $\begin{array}{l}\text { Severe damage to most } \\
\text { buildings and several } \\
\text { thousand kilometers across. }\end{array}$ & 1 per $5-50$ years. \\
\hline 10.0 or over & Massive & $\begin{array}{l}\text { Never recorded. Devastation } \\
\text { across large areas. }\end{array}$ & Never recorded. \\
\hline
\end{tabular}

Earthquake damage to buildings is primarily caused by horizontal accelerations, reported as a percent of gravity. The U.S. Geological Survey creates acceleration maps as part of their National Seismic Hazard Maps. The maps for the years 2008 and 2014 are presented in Figure 16. The image shows that the southeastern part of Missouri has a high percentage of hazards (48 and higher). According to this source, our area of analysis has an 8 to $16 \%$ probability of an earthquake. Figure 17 shows the location of documented earthquakes for the period 1973 to 2012. According to that image, earthquakes occur in southeastern Missouri where the fault is located and no earthquakes have occurred in our area of analysis. Additionally, Figure 18 displays a more recent 2014 version of the hazard map and provides a closer look at Missouri and its counties. According to that image, the hazard percentage ranges from 4 to 20 percent.

Fort Leonard Wood has felt a total of five earthquakes since 1931. The strongest one was in 1991 and it had a magnitude of 3.3, according to the Homefacts website. Local epicenters are displayed in Figure 17. The site is also assigned a 0.49 percent probability of a 5.0 earthquake event within the next 50 years and 50 kilometers. According to the USGS 2014 seismic hazard map for Missouri, Fort Leonard Wood is in a zone with potential for a peak ground acceleration (PGA) at an intensity of 10-14\% of gravity (Figure 18). In summary, due to its proximity to the NMSZ, earthquakes are considered an impact threat to Fort Leonard Wood. Although the epicenter is not located within our area of interest, earthquake damages could extend into our AOI. 
Figure 16. Potential earthquake acceleration potential as a percent of gravity for the year 2008 and 2014. (Source: USGS.)
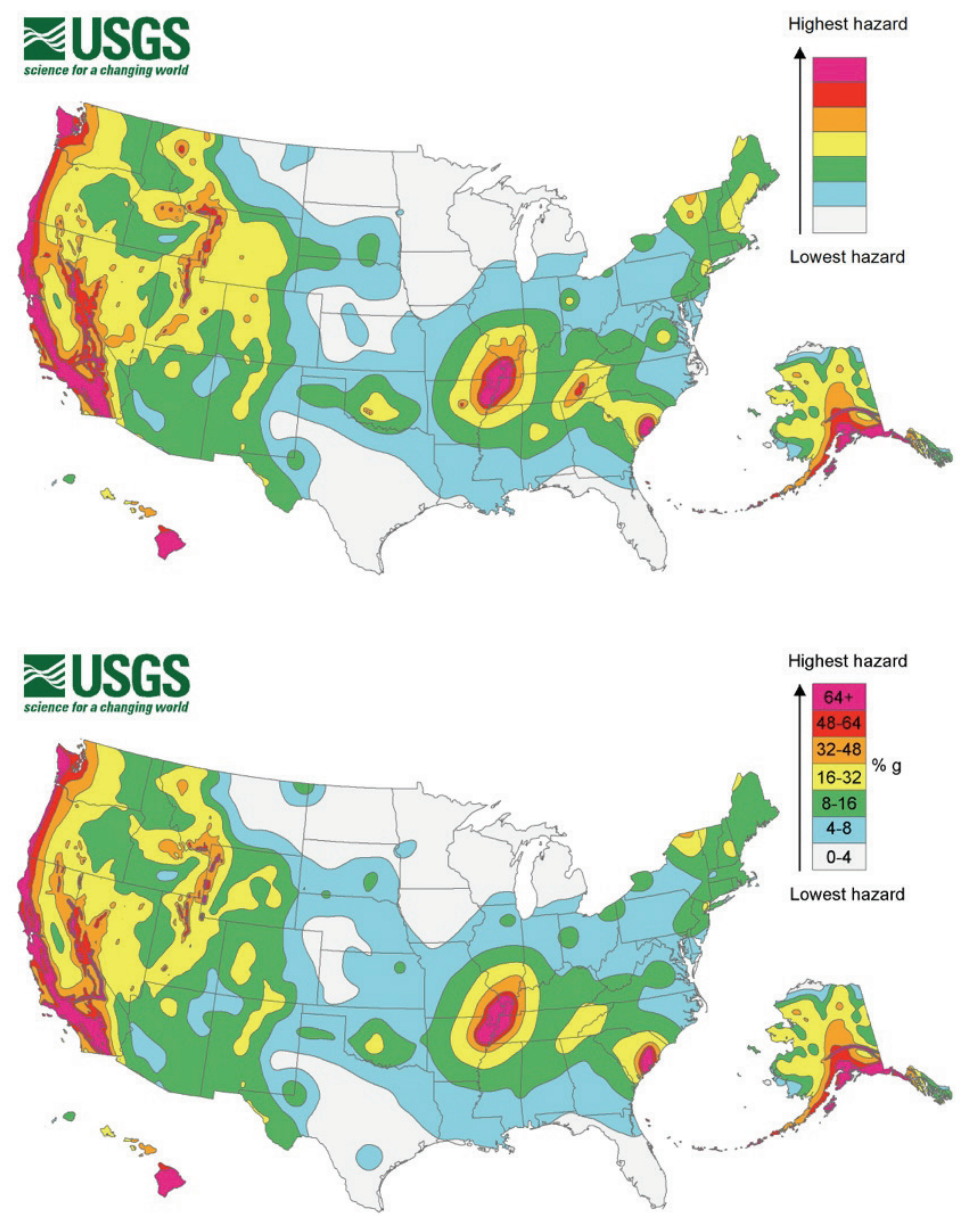

Figure 17. Missouri seismicity map for the years 1973 to 2012. (Source: USGS Earthquake Hazard Program.)

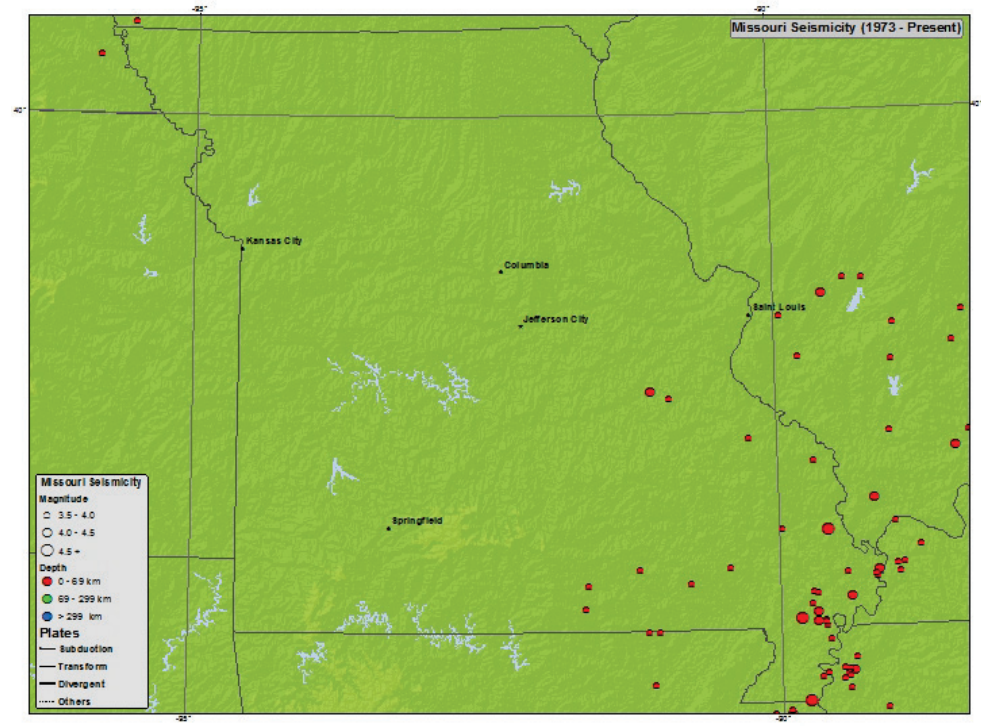


Figure 18. Missouri seismic hazard map. (Source: USGS Earthquake Hazard Program).

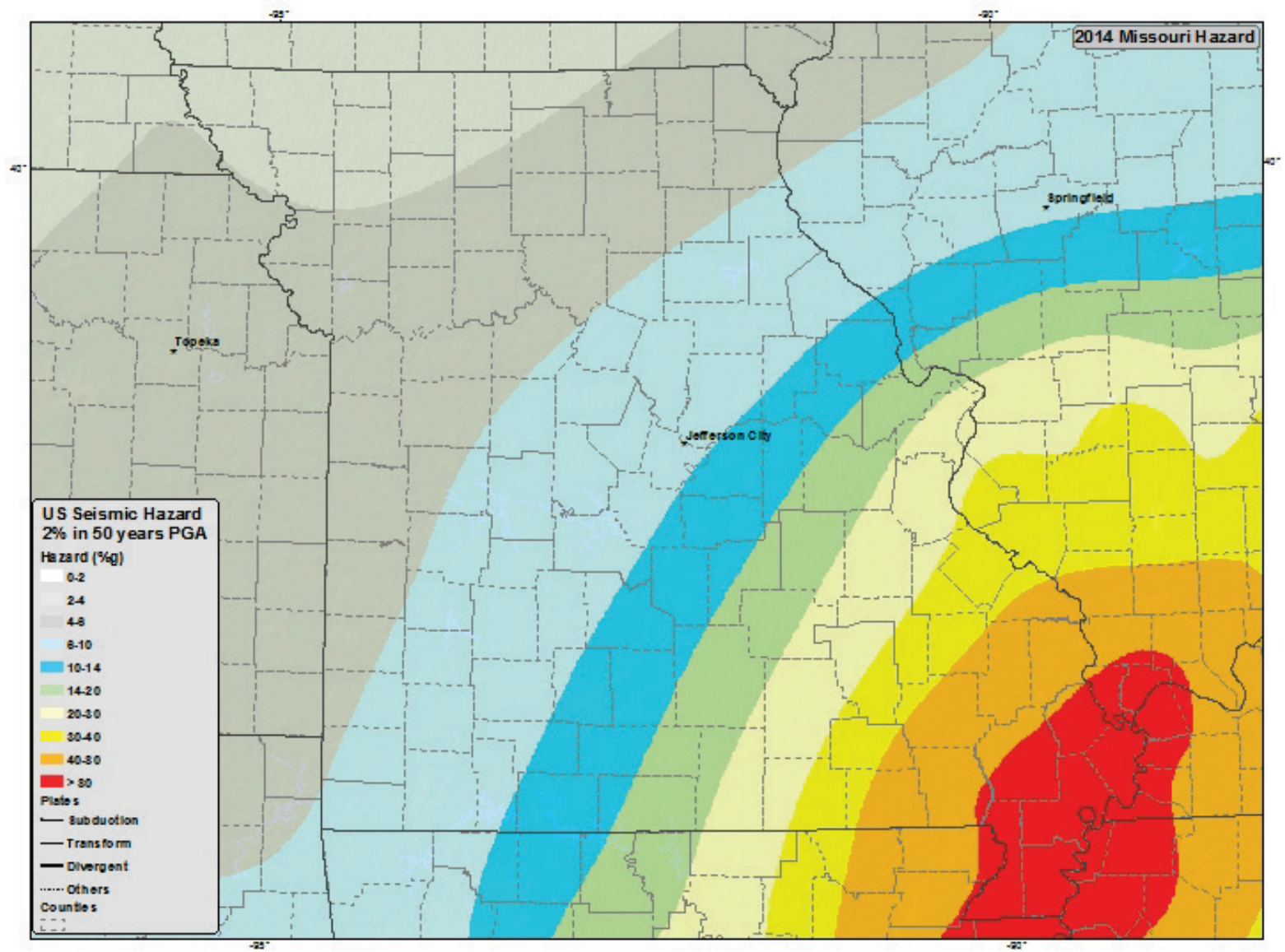

\subsection{Planning measures}

A NMSZ earthquake cannot be predicted. Therefore, preparation for before, during, and after this event are of utmost importance. Emphasis should be given to the capacity of a building to withstand the movement caused by this type of event. Fort Leonard Wood must verify if its entire infrastructure is in compliance with the seismic building codes. Unfortunately, these codes are not law in Missouri and depend on local jurisdiction (International Code Council 2010). Figure 19 shows the high seismic risk counties and if they have accepted seismic code building in the design of commercial buildings. According to ISO BCEGS data, by 2010 only four jurisdictions had adopted seismic building codes for residential and commercial structures. So, the first step would be to verify if Fort Leonard Wood infrastructure was designed with seismic-resistant building codes. Importance should also be given to the reinforcement of the Army installation and its perimeter. For example, trees that are considered to be weak and could cause harm should be removed. Other simple things that can be 
done before an earthquake occurs are placing heavier or breakable objects on lower shelves or cabinets, verify that shelves are correctly fastened to walls, fixing existing cracks on floors and walls. Proper training for the military and civilian personnel is also recommended.

Figure 19. Seismic building code compliance in high-risk counties. (Source: 2010 ISO BCEGS Data.)

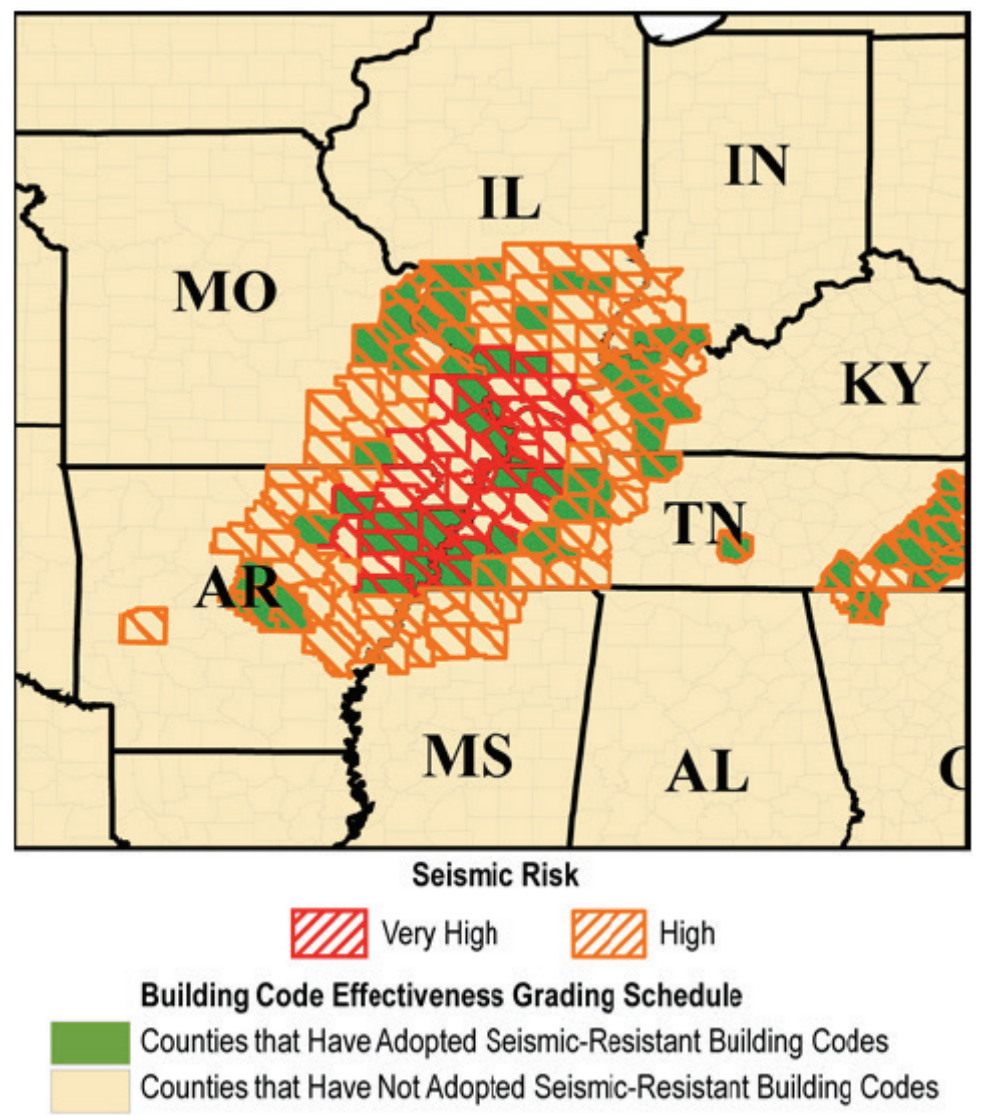




\section{Sinkholes}

\subsection{Potential events}

Missouri is mostly underlain by carbonate bedrock or karst terrain. Dolomite and limestone, two of the components of the bedrock, are highly reactive with acidic water, causing their dissolution and creating bedrock voids. These voids increase in size, and water washes away any soil from the overlying surface that falls into them. Eventually, a sinkhole is formed (Figure 20). A sinkhole can also be formed from the collapse of underlying caves. Most of the sinkholes have a circular depression pattern.

Figure 20. Sample sinkhole. (Source: http://blogs.mo.gov/geology/tag/sinkhole/)

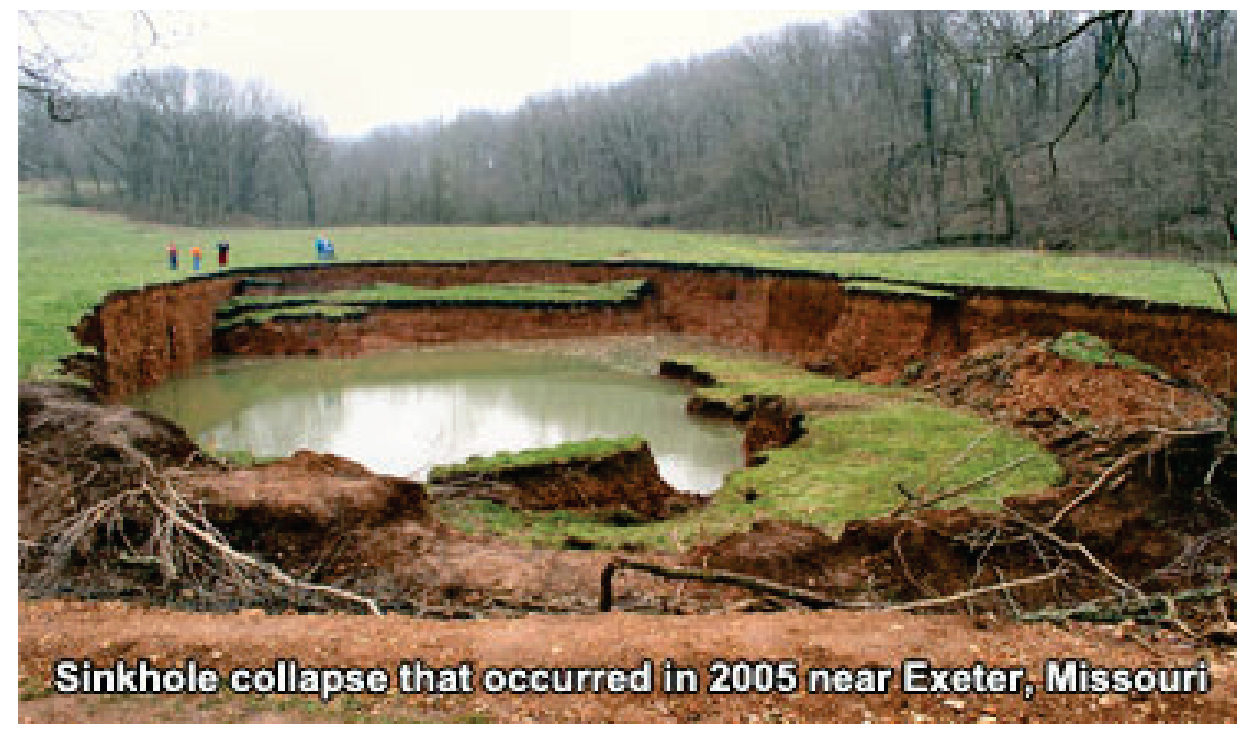

Fort Leonard Wood is located over the Salam Plateau Region, one of the primary sinkhole regions of Missouri (Missouri Geological Survey). The Missouri Department of Natural Resources, Geological Survey Program map shows documented or reported sinkholes found in Missouri (Figure 21.) The website provides the option of downloading a GIS layer. According to this source, more than 2,086 sinkholes are located in our AOI. 
Figure 21. Missouri sinkhole locations. (Source: Missouri Department of Natural Resources, http://dnr.mo.gov/geology/geosrv/envgeo/sinkholes.htm)

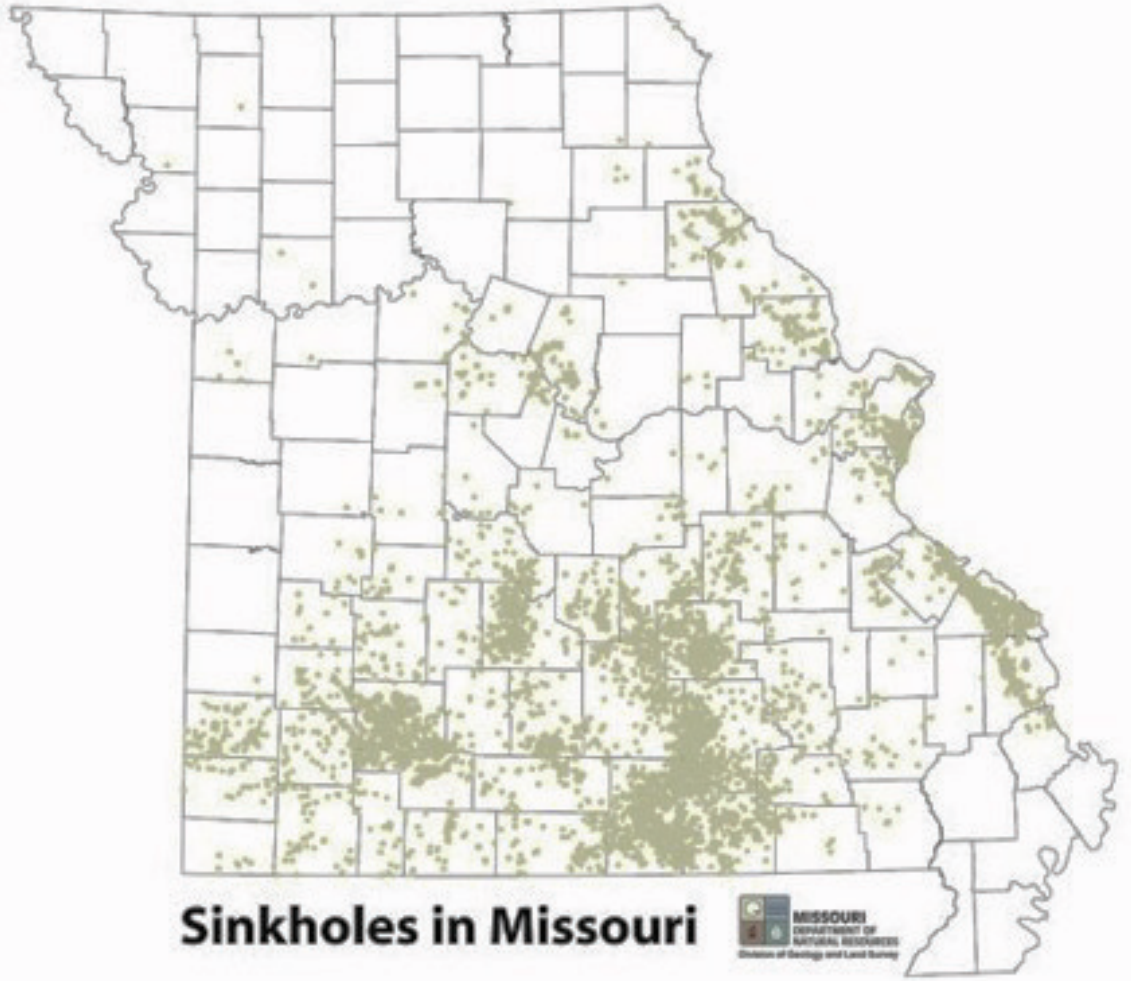

\subsection{Planning measures}

Ideally it would be optimal to locate areas where a sinkhole might form. Future sinkholes can sometimes be detected with sound and groundpenetrating radar techniques to identify subterranean caves. Before a full collapse, the land above a cave can begin to subside. This can accelerate the erosion of underlying limestone by collecting, redirecting, and focusing rainwater to the center of the subsidence area. Areas of subsidence can be identified as areas where rain does not drain away, nor collect. Such areas can be identified in LiDAR (Light Detection And Ranging) data. Figure 22 depicts an area around and including the Fort Leonard Wood cantonment, which appears whitish across the right and lower center area of the image. The background is a satellite image with the south-facing slopes of hills more illuminated than the north-facing slopes. Stream courses are depicted in blue. Reddish patches are depressions in the LiDAR data and could be associated with actual depressions that might reflect a future sinkhole.

Conducting a survey of the installation guided by LiDAR data analysis could identify locations to avoid in future construction plans or to monitor when they are already associated with human activity. 
Figure 22. Potential Fort Leonard Wood sinkholes shown in red.

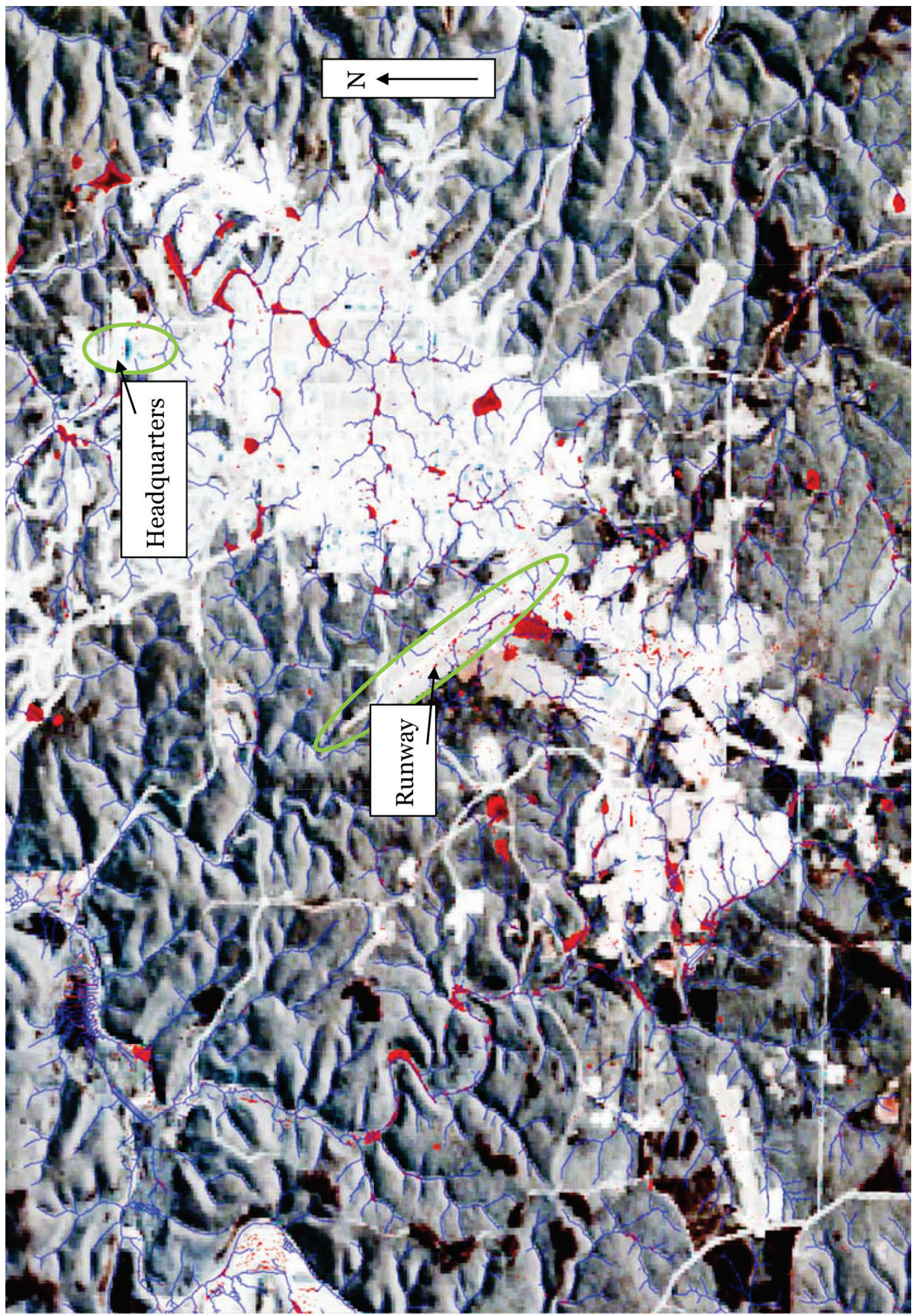




\section{Emerging Impacts of Climate Change}

The 2010 and 2014 Quadrennial Defense Reviews declared that climate change will affect Department of Defense (DoD) and that DoD will need to adjust to the impacts of climate change on its facilities. These were followed by the DoD Climate Change Adaptation Roadmap (2012 and 2014), which established goals for considering climate change with respect to potential effects and changes needed to existing processes involved with training and testing, and the built and natural infrastructure. Changes associated with climate change to be considered include rising temperatures, altered precipitin patterns, increasing storm frequency and intensity, rising sea levels, and changes in ocean temperature, circulation, salinity, and acidity. Army policy and guidance is being developed in response to these DoD requirements.

\subsection{Potential effects}

Climate can be defined as the range of weather conditions at a given location experienced over decades of time. Climate variability can also be defined as how conditions change year to year. Continental locations, like Fort Leonard Wood, can experience cool or warm summers, which can also be wetter or drier. This is not climate change, but rather climate variability, which earlier sections of this document consider. But climate does change and has continually changed through the history of the earth. Dinosaurs have lived in Arctic areas at times, and glaciers have covered much of North America at other times. Historically, change has been driven by such things as solar output, precession of earth's tilt and orbit, volcanic eruptions and their associated dust and gas, and changes in the forms of life inhabiting the earth. These changes continue to occur and shifts in climate around the earth through historic times can be directly attributed to these natural causes.

Figure 23 plots deviations of average temperatures in the Midwestern U.S. over the past century. Annual temperatures varied by more than $8{ }^{\circ} \mathrm{F}$, reflecting climate variability. In that time period, the average temperature has increased by $1.5^{\circ} \mathrm{F}$, based on the application of a linear regression analysis to the data. The National Climate Assessment analysis of recent changes in the frequency of very heavy precipitation events is captured in Figure 24. Data from 1958 to 2012 shows the upper Midwest has been ex- 
periencing $45 \%$ more severe storms. These temperature and precipitation trends are based solely on simple analyses of historic measured data and indicate that indeed, the climate is changing, although that signal is only detectable against year-to-year climate variability by analyzing many decades of weather data.

The continued shift in climate suggests that new extremes are expected with respect to high temperatures and higher rainfall amounts, thus leading to even more intense future black swan events. But, is this increase expected to be linear, increasing in the rate of change, or decreasing?

Figure 23. Historic increasing temperature trend in Midwest.

(Source: National Climate Assessment.)

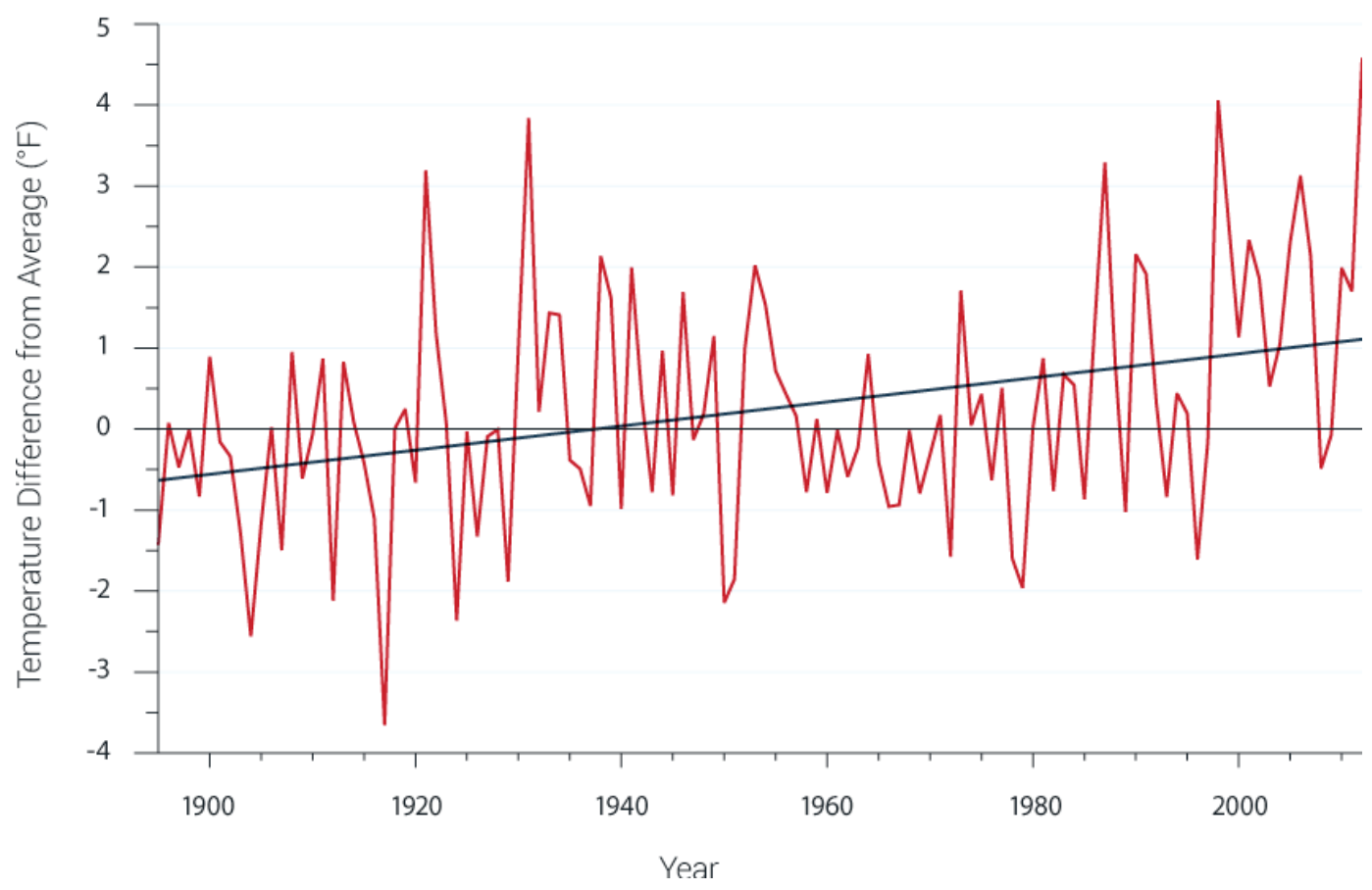


Figure 24. Recent increases in very heavy precipitation.

(Source: National Climate Assessment.)

\section{Percentage Change in Very Heavy Precipitation}

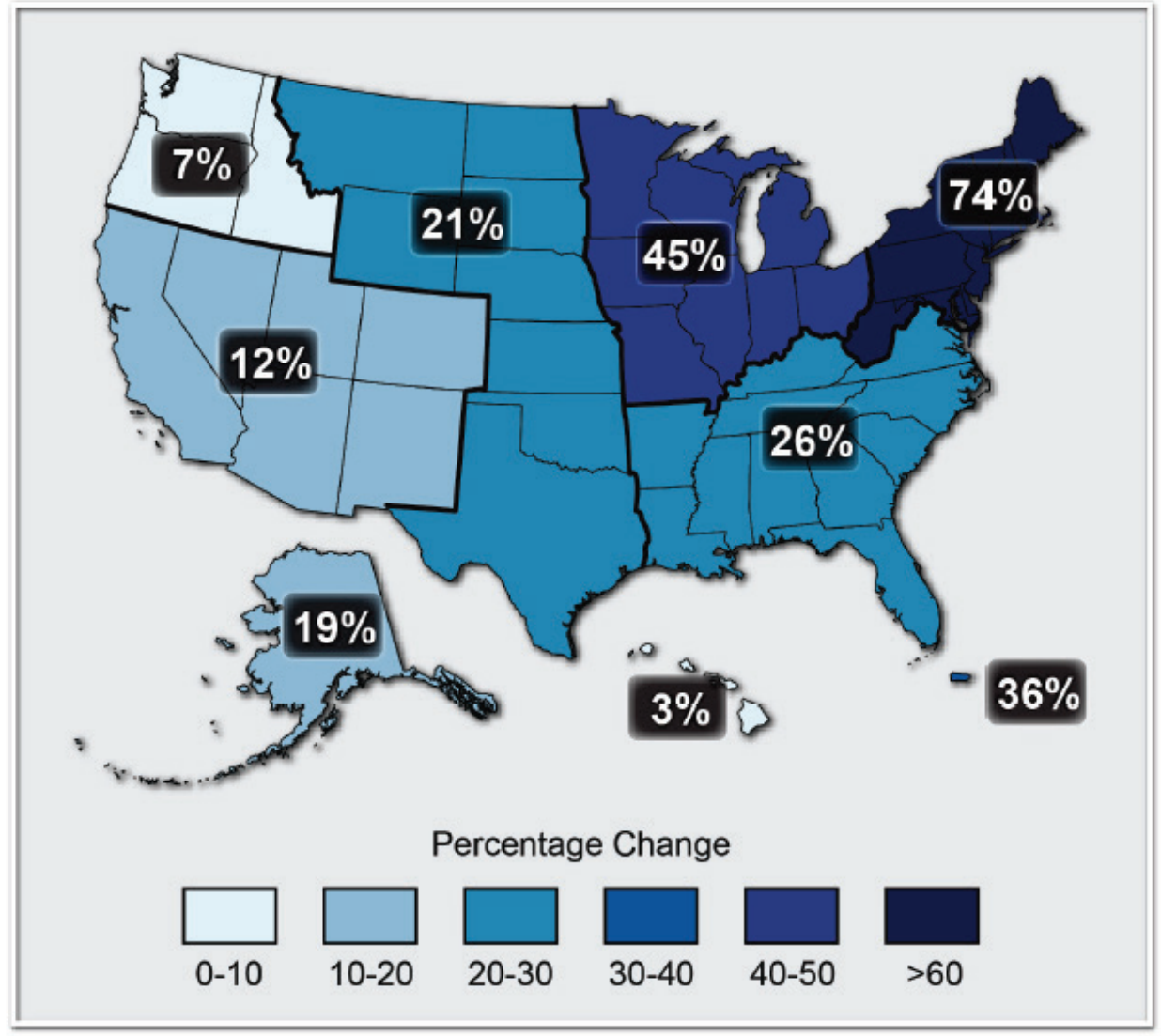

To attack the question of what the future climate will look like, climatologists have developed sophisticated supercomputer-based weather simulation models that capture the circulation of atmospheric and oceanic currents driven by seasonal, solar, and human activities. These general circulation (GCM) models also consider atmospheric and oceanic chemistry, human use of land and rivers, and natural cycles of plant growth. One of the key variables in the model is the concentration of greenhouse gases. Some of the gasses in the atmosphere allow much of the solar radiation to pass through and heat the earth, but don't allow the infrared radiation from the heated earth to pass back into space. The most notable of these gases include water vapor, methane, and carbon dioxide. Increasing any of these gases increases the amount of energy retained in the atmosphere and the oceans. There is now an extremely strong consensus that the recent changes in climate have been greatly influenced by anthropogenic processes that release to the atmosphere huge amounts of carbon dioxide. 


\subsection{Planning considerations}

The first time that biological processes altered the climate of the earth was when ancient blue-green algae feasted on the abundant carbon dioxide, dropping the atmospheric and oceanic concentrations of this gas and replacing it with oxygen. As a result, the earth turned from being extremely warm to being extremely cold, eventually covered mostly by ice. The captured carbon was deposited and became part of the earth's crust. That carbon is now being mined and burned, resulting in increasing concentrations of carbon dioxide back into the oceans and air.

GCM models are generating future pictures of climate across the globe. Collectively, model outputs suggest that extreme heat events will be more frequent, more severe, and longer. Additionally, it is predicted that high temperature events that occurred every twenty years, will occur more frequently, every two to four years. A 2009 study from the U.S. Global Change Research Program mentions that cold periods are occurring with lesser frequencies, and hot periods are more frequent. This pattern is forecasted to be accompanied by a summer temperature increase of $3{ }^{\circ} \mathrm{F}$ and $10{ }^{\circ} \mathrm{F}$ by the end of the century.

The National Climate Assessment (NCA) report describes changes expected due to climate change. According to this study, more extreme weather events, with higher intensities and frequency, are expected in the Midwest. The models suggest that over the century, mean temperatures can be expected to increase 3 to $8^{\circ} \mathrm{F}$ resulting in an increase in fire-risk days (Figure 25) and increased heat-restricted training days (Figure 26). According to health and safety standards, black training times require 50 minutes of rest for every 10 minutes of work and red times require 40 minutes of rest for every 20 minutes of work. Note that these values change during the day and what is predicted is the number of days during which the restriction hits the highest level, not the number of full days where substantial training is lost. Nevertheless, Fort Leonard Wood becomes similar to current areas further south. 
Figure 25. Forecasted change in fire risk days.

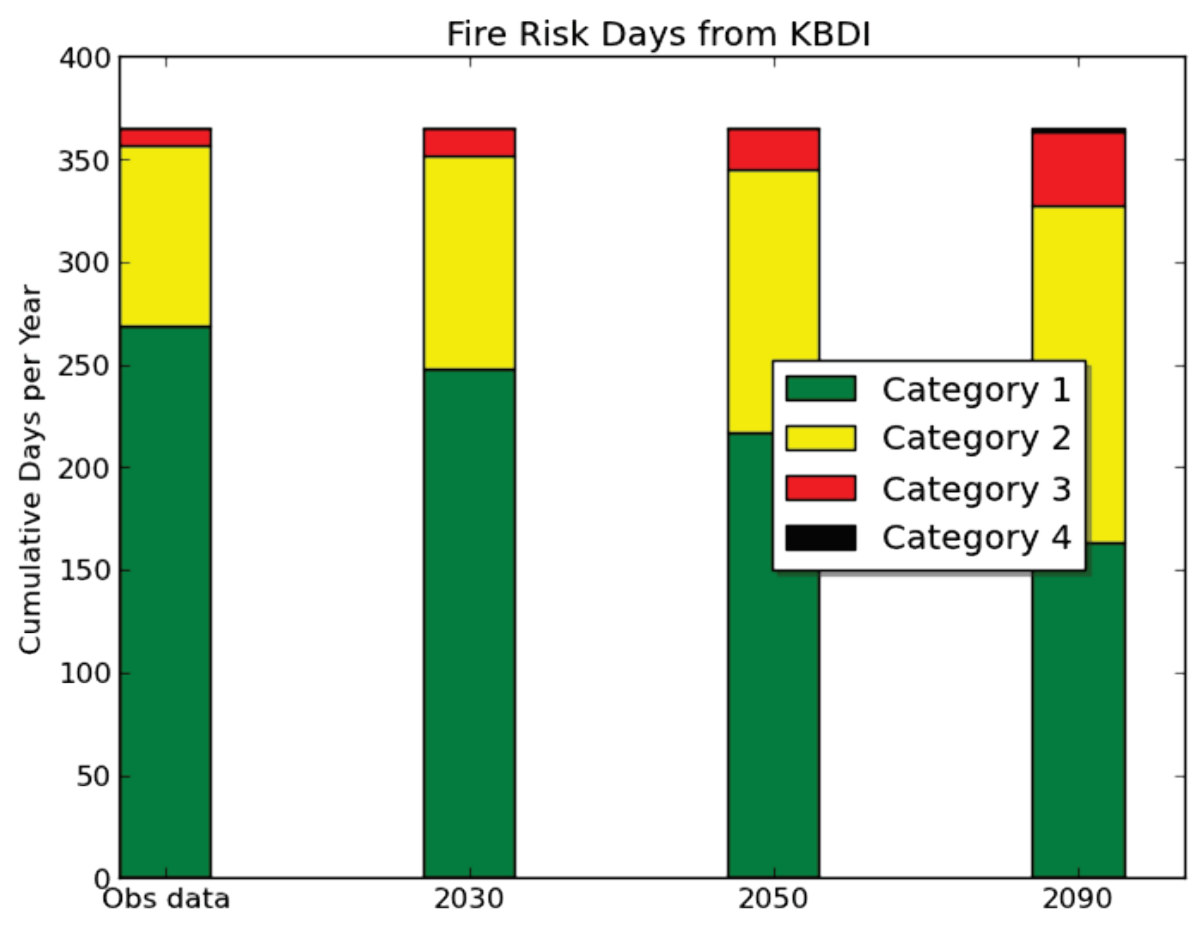

Figure 26. Forecasted change in heat-restricted training days.

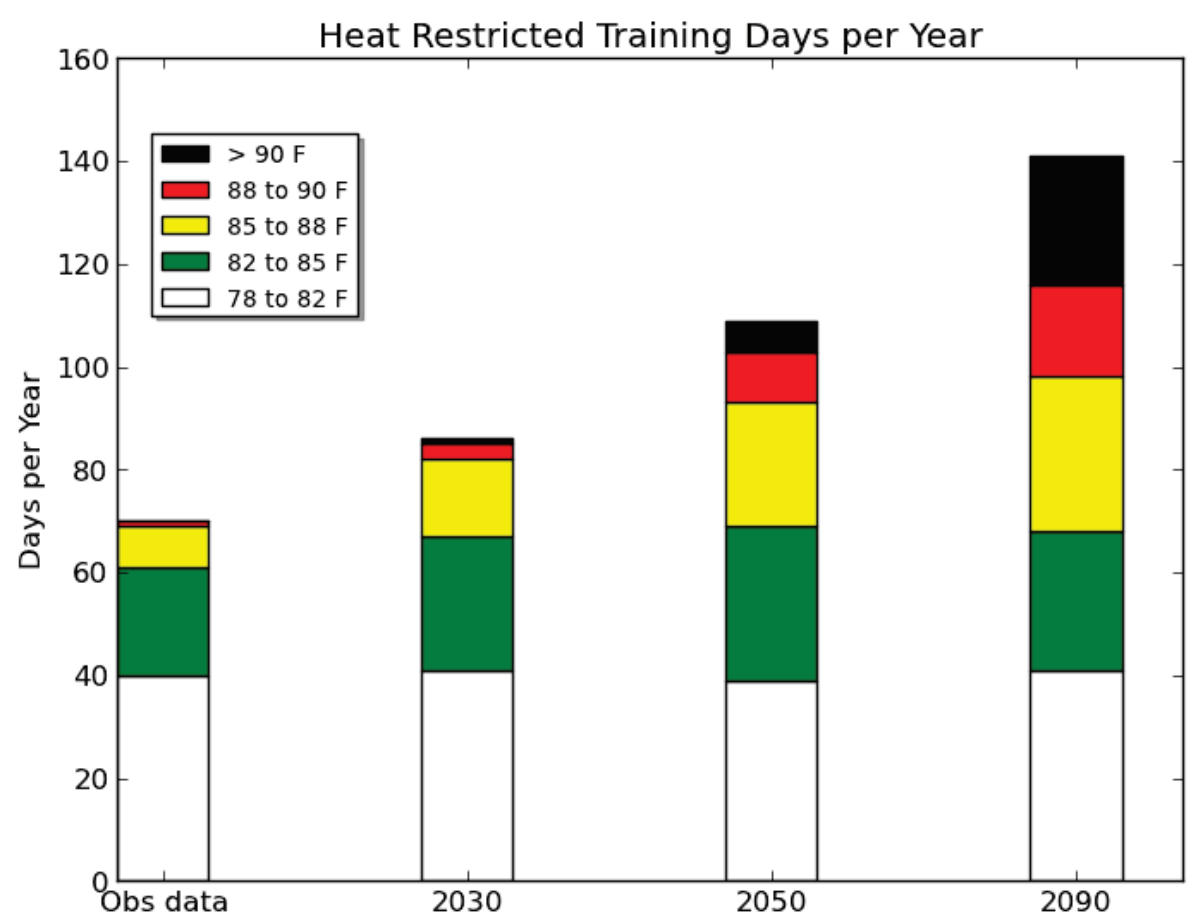

With increasing temperatures, changes would be expected in heating and air conditioning costs. A study was conducted using 495 buildings modeled in Net Zero Planner and weather files adjusted for an increase of $3{ }^{\circ} \mathrm{C}$ 
$\left(5.4{ }^{\circ} \mathrm{F}\right)$ and $6{ }^{\circ} \mathrm{C}\left(10.8{ }^{\circ} \mathrm{F}\right)$ scenarios with relative humidity held constant. The results can be found in Table 8 . The key findings are as follows:

- Heating loads (gas) decrease and cooling loads (electrical) increase.

- Site gas energy decreases $3.5 \%$ with a temperature increase of $3{ }^{\circ} \mathrm{C}$ and $4.6 \%$ with an increase of $6{ }^{\circ} \mathrm{C}$

- Electrical energy increases $2.4 \%$ and $6.5 \%$, due to shift from natural gas to electricity, assuming no cogeneration

- Overall, energy COST increases $2.3 \%$ and $6.2 \%$

Table 8. Estimated change in energy consumption under climate temperature increases of $3^{\circ} \mathrm{C}$ and $6{ }^{\circ} \mathrm{C}$.

\begin{tabular}{|c|c|c|c|c|c|c|}
\hline $\begin{array}{c}\text { Scenari } \\
0\end{array}$ & $\begin{array}{l}\text { Site Total } \\
\text { (kBtu) }\end{array}$ & $\begin{array}{c}\text { Site } \\
\text { Electricity } \\
\text { (kBtu) }\end{array}$ & $\begin{array}{l}\text { Site Gas } \\
\text { (kBtu) }\end{array}$ & $\begin{array}{l}\text { Site Elec } \\
\text { Cost }(\$)\end{array}$ & $\begin{array}{l}\text { Site Gas } \\
\text { Cost }(\$)\end{array}$ & $\begin{array}{l}\text { Site Total } \\
\text { Cost (\$) }\end{array}$ \\
\hline $\begin{array}{l}\text { No } \\
\text { change }\end{array}$ & $\begin{array}{l}790,226,86 \\
1\end{array}$ & $\begin{array}{l}460,695,16 \\
5\end{array}$ & $\begin{array}{l}329,531,69 \\
6\end{array}$ & $\begin{array}{l}\$ 12,151,47 \\
8\end{array}$ & $\begin{array}{l}\$ 2 \\
6\end{array}$ & $\begin{array}{l}\$ 1 \\
4\end{array}$ \\
\hline $\begin{array}{l}\text { Plus } 3 \\
{ }^{\circ} \mathrm{C}\end{array}$ & $\begin{array}{l}762,742,65 \\
6\end{array}$ & $\begin{array}{l}493,227,32 \\
2\end{array}$ & $\begin{array}{l}269,515,33 \\
4\end{array}$ & $\begin{array}{l}\$ 13,099,55 \\
9\end{array}$ & $\begin{array}{l}\$ 2,316,28 \\
1\end{array}$ & $\begin{array}{l}\$ 15,325,84 \\
0\end{array}$ \\
\hline $\begin{array}{l}\text { Plus } 6 \\
{ }^{\circ} \mathrm{C}\end{array}$ & $\begin{array}{l}754,053,56 \\
0\end{array}$ & $\begin{array}{l}530,566,06 \\
7\end{array}$ & $\begin{array}{l}223,487,49 \\
3\end{array}$ & $\begin{array}{l}\$ 13,994,42 \\
1\end{array}$ & $\begin{array}{l}\$ 1,920,70 \\
6\end{array}$ & $\begin{array}{l}\$ 15,915,12 \\
7\end{array}$ \\
\hline
\end{tabular}

Anyone who travels around the country knows that as they travel into different climate areas they experience different ecosystems. This has led to the development of ecosystem maps of the U.S. and we have statistically correlated ecosystems with climate characteristics, which allowed us to project future ecosystem areas based on the projected climate changes. The top-right image in Figure 27 displays the extent of historic ecosystems in southern Missouri around Fort Leonard Wood, as characterized by The Nature Conservancy. The installation is firmly within the Ozarks (dark purple) ecosystem. The second row has projections for 2050 with the first two columns associated with the Parallel Climate Model (PCM), a General Circulation Model (GCM) developed by several U.S. agencies. This model tends to be associated with less aggressive projections. The rightmost two columns are associated with projections from the Hadley (HAD) model, developed by the United Kingdom's Hadley Centre for Climate Prediction and Research, which tends to project more dramatic climate changes. The first and third columns are based on greenhouse gas emission stories that result in relatively less $\mathrm{CO} 2$ (the $\mathrm{B} 1$ scenario) while the second and forth are based on scenarios suggesting greater emissions (the A1 scenario). Fi- 
nally, the last row is identical, except the results are associated with 2100 projections. The results of the PCM model running the lower emission scenario paint a picture of the ecosystems around Fort Leonard Wood remaining pretty much the same, as is true of the PCM model running with the higher emission story line out to 2050. However, most of the remaining GCM simulation results suggest that Fort Leonard Wood will be welcoming a shift to the climate currently associated with the Ouachita Mountains (the rust color), an ecosystem currently spanning eastern Oklahoma and west-central Arkansas. Finally, the aggressive emission model associated with the more aggressive Hadley model results in sets of climate characteristics that, collectively, are not currently associated with any U.S. ecosystem type. 
Figure 27. Projected ecosystem shifts.

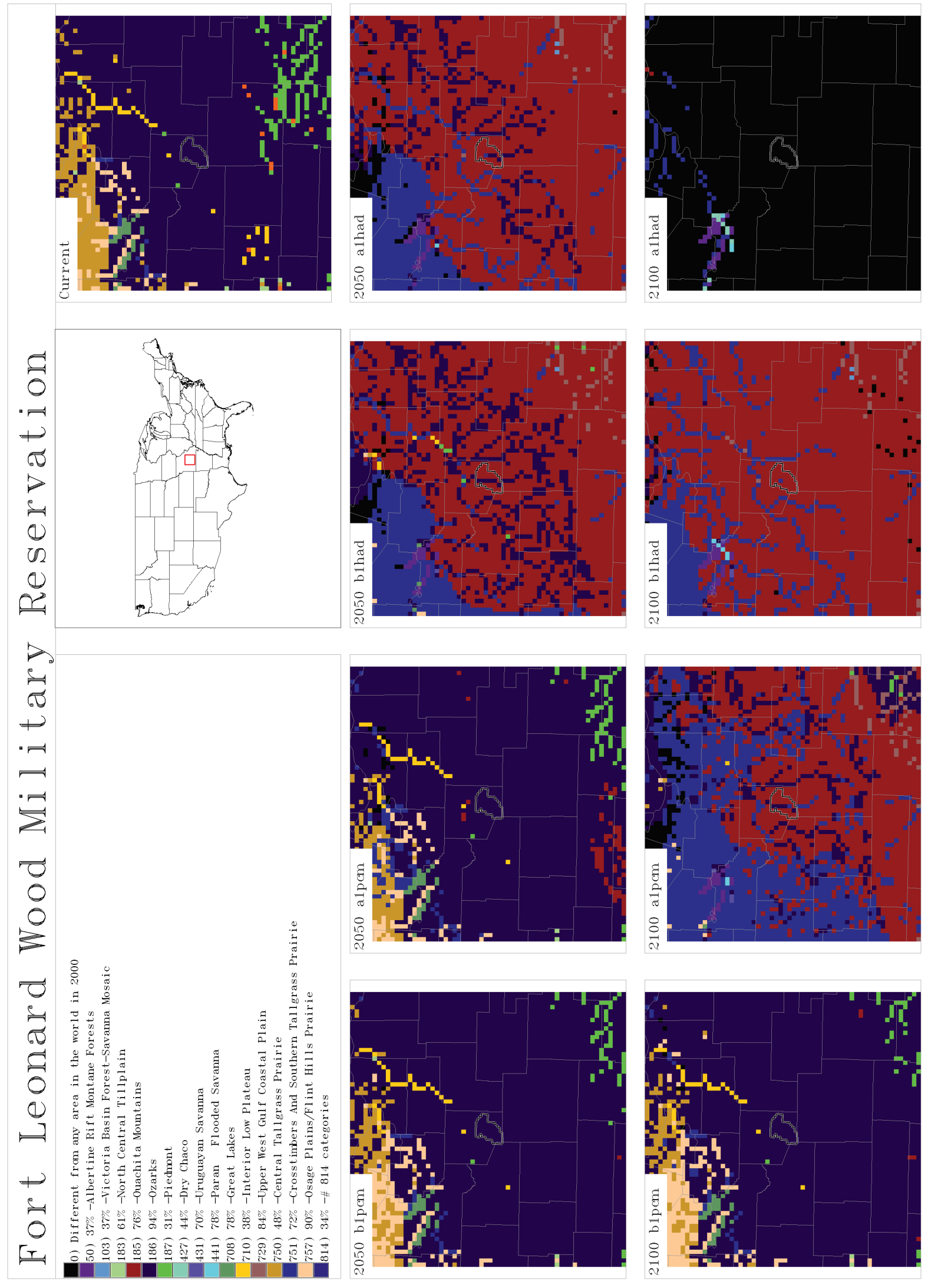




\section{Discussion and Summary}

Disaster planning generally results in preparation for responses to repeats of historic disasters, especially those that are most memorable; recent, and consequential. There is a class of disasters that are often overlooked, referred to as black swan events. These are defined as rare and improbable events and presumed not appropriate for inclusion in disaster planning. However, once they occur, they are considered very appropriate for inclusion in disaster planning. This report attempts to illuminate potential disaster events that might be wisely considered in future disaster planning.

Fort Leonard Wood sits in south-central Missouri, an area with historic weather extremes. Historic temperature extremes have been recorded from $-40{ }^{\circ} \mathrm{F}$ to $118^{\circ} \mathrm{F}$, with temperatures increasing in the Midwest at the rate of nearly $2{ }^{\circ} \mathrm{F}$ over the last century. Climate models estimate another $3{ }^{\circ} \mathrm{F}$ to $10{ }^{\circ} \mathrm{F}$ increase by the end of the $21^{\text {st }}$ century. Another aspect of Fort Leonard Wood's mid-continental weather is that the region experiences relatively high numbers of thunderstorms and tornados. Some of the largest hourly rainfalls and largest tornados (an F-5) have occurred in the region and should be considered future threats.

Recent changes in climate across the Midwest include increasing numbers of the largest rain events, hence increasing the probability of a Fort Leonard Wood black swan rainstorm. Consideration should be given to the consequence of such a storm with respect to culverts, stream and river crossings, and general flooding.

The region sees a lot of climate variability that could result in prolonged deep droughts such as the one that contributed to the dust bowl in the 1930 s and the profound 3-year drought in the mid-1950s. Most people now working in the Fort Leonard Wood area have not experienced a drought of this magnitude, but the repercussions of this type of event should be considered. The consequences to drinking water, forest fire potential, and habitat/species impact could be dramatic.

The area is co-located with one of the most dangerous earthquake zones in the U.S., the New Madrid Fault. Earthquake experts suggest that the areas 
that would be most devastated do not include the Fort Leonard Wood area, but this area does lie in an above-average danger zone.

Finally, the entire area sits on a continental crust composed of limestone that has been dissolved and carved out underground by running water. Slightly acidic rainwater flows into underground passages where the limestone is slowly, but persistently removed to create caves. Missouri is famous for cave collapses that dramatically create sinkholes. Human structures such as buildings and roads can drop into the ground in a moment swallowing vehicles and people with it. With increased rainfall and increased carbon dioxide in the rainwater (making it acidic), the rate of sinkhole creation is accelerated. Identification of potential sinkhole areas would be extremely useful when planning the location of new structures and for identification of cave-in potentials under existing structures.

It is hoped that this report will encourage black swan event discussions at Fort Leonard Wood that potentially lead to better preparation for unusual (until they happen) natural disaster events. 


\section{References}

Bridger, C.A., F.P. Ellis, H.L. Taylor. 1976. Mortality in St. Louis, Missouri, during heat waves in 1936, 1953, 1954, 1955, and 1966. Environmental Research 12:38-48.

Elnashai, A. S., T. Jefferson, F. Friedrich, L.J. Cleveland, and T. Gress. 2009. New Madrid Seismic Zone Catastrophic Earthquake Response Planning Project: Impact of New Madrid Seismic Zone Earthquakes on the Central USA. Mid-America Earthquake Center, Report No. 09-03.

Landoll, D. J. 2011. The Security Risk Assessment Handbook: A Complete Guide for Performing Security Risk Assessments, Second Edition. 495 pp. Boca Raton, FL: CRC Press.

Lott, G. 1954. The World-Record 42 Minute Holt, Missouri, Rainstorm. Monthly Weather Review, February 1954, pp 50-59.

Melillo, J. M., T. Richmond, and G.W. Yohe. 2014. Climate Change Impacts in the United States: The Third National Climate Assessment. U.S. Global Change Research Program, 841 pp. doi: 10.7930/JoZ31WJ2.

Sikula N., J.W. Mancillas, I. Linkov, and J.A. McDonagh. 2015. "Risk management is not enough: A conceptual model for resilience and adaptation-based vulnerability assessments." Environment Systems and Decisions 35(2).

Taleb, N. N. 2007. The Black Swan: The Impact of the Highly Improbable. New York, NY: Random House. 


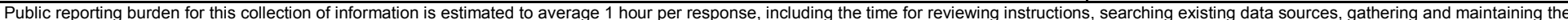

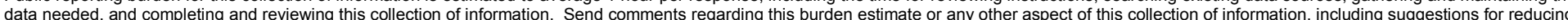

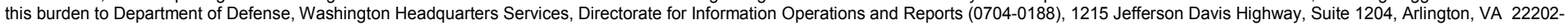

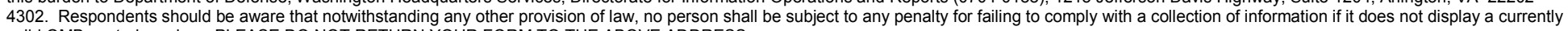
valid OMB control number. PLEASE DO NOT RETURN YOUR FORM TO THE ABOVE ADDRESS.
1. REPORT DATE (DD-MM-YYYY)
March 2016

\section{Final}

4. TITLE AND SUBTITLE

Black Swan Event Assessment for Fort Leonard Wood, Missouri

Grace M. Diaz-Estrada and James D. Westervelt

3. DATES COVERED (From - To)

5a. CONTRACT NUMBER

5b. GRANT NUMBER

5c. PROGRAM ELEMENT NUMBER

5d. PROJECT NUMBER

MIPR 10599341

5e. TASK NUMBER

5f. WORK UNIT NUMBER

8. PERFORMING ORGANIZATION REPORT NUMBER

7. PERFORMING ORGANIZATION NAME(S) AND ADDRESS(ES)

U.S. Army Engineer Research and Development Center

Construction Engineering Research Laboratory

2902 Newmark Drive

Champaign, IL 61822

ERDC/CERL SR-16-1

\section{SPONSORING / MONITORING AGENCY NAME(S) AND ADDRESS(ES)}

10. SPONSOR/MONITOR'S ACRONYM(S)

Plans, Analysis, and Integration Office (PAIO)

U.S. Army Garrison Fort Leonard Wood

Fort Leonard Wood, MO 65473

11. SPONSOR/MONITOR'S REPORT NUMBER(S)

\section{DISTRIBUTION / AVAILABILITY STATEMENT}

Approved for public release; distribution is unlimited.

\section{SUPPLEMENTARY NOTES}

\section{ABSTRACT}

Emergency preparation typically involves evaluating disaster potential and consequences, followed by disaster preparedness. Potentials are informed by history, with the easy human belief that we must obviously prepare for the past. There is a class of disasters that involve events that may not have been anticipated, but in hindsight appear to be obviously overlooked. This report attempts to identify such black swan events, potential disasters in the Fort Leonard Wood area that might well attract more attention in future planning exercises.

\section{SUBJECT TERMS}

Net Zero planning, risk assessment, emergency management, hazard mitigation, military bases, natural disasters, Fort Leonard Wood, MO

\begin{tabular}{|c|c|c|c|c|c|}
\hline \multicolumn{3}{|c|}{ 16. SECURITY CLASSIFICATION OF: } & 17. LIMITA & 18. NUMB & 19a. NAME OF RESPONSIBLE PERSON \\
\hline $\begin{array}{l}\text { a. REPORT } \\
\text { Unclassified }\end{array}$ & $\begin{array}{l}\text { b. ABSTRACT } \\
\text { Unclassified }\end{array}$ & $\begin{array}{l}\text { c. THIS PAGE } \\
\text { Unclassified }\end{array}$ & & 57 & $\begin{array}{l}\text { 19b. TELEPHONE NUMBER (in- } \\
\text { clude area code) }\end{array}$ \\
\hline
\end{tabular}

